\section{Autonomy or Efficiency. An experiment on household decisions in two regions of India}

\section{by Alistair Munro, ${ }^{\star *}$ Bereket Kebede, Marcela Tarazona-Gomez and Arjan Verschoor.*}

* School of Development Studies, University of East Anglia, Norwich, NR4 7TJ, UK

** National Graduate Institute for Policy Studies, 7-22-1 Roppongi, Minato-ku, Tokyo 106-8677, Japan.

\begin{abstract}
Dyson and Moore (1983) posit that women in South India enjoy relatively more agency than in the North. Their conclusions have become part of the standard picture of Indian rural society. In this paper, we examine using experimental data the implications of this regional contrast in female autonomy for the efficiency of family decision-making. We take a sample of 1200 couples from two areas in the north of India (Uttar Pradesh) and one area in the south (Tamil Nadu) that are often taken to exemplify differences in the autonomy of women and the nature of marital relationships. Generally, we find large-scale and robust evidence of inefficiency and the hiding of assets when this is possible. Men invest more and are more generous to their partners. Women are more willing to invest in a common pool when their income is earned through working and when assets are publicly observable.
\end{abstract}

Regarding the focus of our paper, we find continuing significant differences between North and South and we find relatively little evidence that urban living is associated with changes in the nature of marital behaviour. There are some differences between response to treatment but the key and striking difference between the North and the South is that in both rural and urban sites in the former region household efficiency is considerably greater than in the latter, which does on the face of it suggest a tradeoff between autonomy and efficiency.

\section{JEL classification codes}

D130, Z130

\section{Keywords}

Economic experiments, married couples, female autonomy, efficiency, intra-household allocation, North and South India, Dyson and Moore

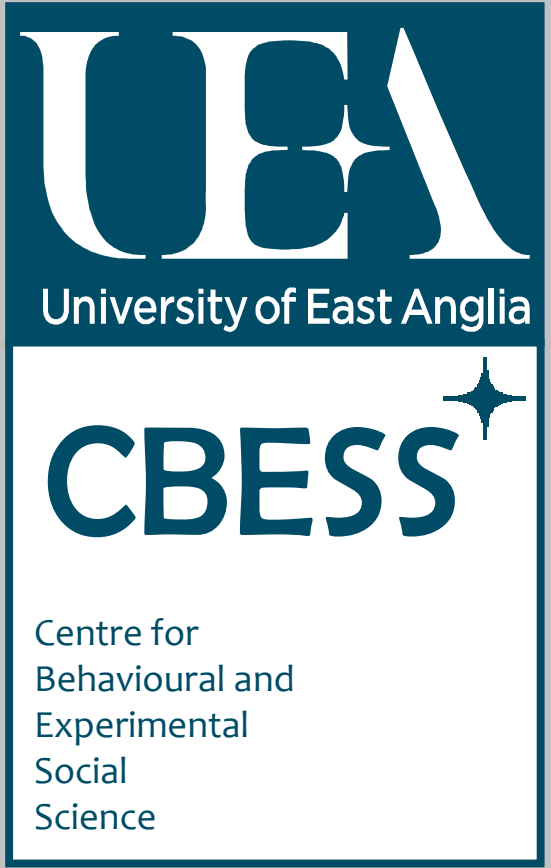

CBESS

University of East Anglia Norwich NR4 7TJ United Kingdom www.uea.ac.uk/ssf/cbess 


\section{Introduction.}

Dyson and Moore (1983) posit that women in South India enjoy relatively more agency than in the North. In this paper, we examine using experimental data the implications of this regional contrast in female autonomy for the efficiency of family decision-making. In theory, independent spousal resource allocation decisions do not need to give rise to household inefficiency. For instance, a greater degree of female autonomy could lead to more weight being given in a bargained Pareto-efficient outcome to her preferences. However, spousal autonomy (compared to a unitary household model) does give rise to the possibility of inefficiency. Spouses independently controlling resources, the more so when they can hide some of these, through the opportunity this gives to pursue fulfilling their own preferences, as well as through coordination problems, creates the potential for sub-optimal household resource allocation decisions.

We take as our point of departure, and as the basis for our site selection, the Dyson and Moore thesis of relatively greater female autonomy in the South, and examine the implications for household efficiency. Though the details of their research have been widely queried, their broad conclusions have become part of the standard picture of Indian rural society. Following Jejeebhoy and Sathar (2001), we take a sample of 1200 couples from two areas in Uttar Pradesh (UP) in the north of India and one area in Tamil Nadu (TN) in the south that exemplify differences in the autonomy of women and the nature of marital relationships. However, since the continued validity of the Dyson and Moore thesis has recently been questioned (Rahman and Rao, 2004), we use extensive interviews with almost all husbands and wives in our sample (interviewed separately) in order to verify that our sites typify the North-South contrast as it is normally held to be in the literature. In particular, we check whether the three avenues we focus on through which spousal autonomy could lead to inefficiency - private endowments, the possibility to hide these, separate spheres of decisionmaking - are significantly different between our northern and southern sites. Each of these avenues is explored separately in our experimental design.

In our baseline experiment, couples play a standard public good game, with private, secret endowments, a voluntary contribution mechanism and a fixed sharing rule of the common pot. Our key treatments allow us to examine the impact on efficiency of earning endowments (to mimic the situation of greater entitlement to one's own resources), public endowments (to

\footnotetext{
* This study forms part of "The Intra-Household Allocation of Resources: Cross-Cultural Tests, Methodological Innovations and Policy Implications", a project jointly funded by the UK's ESRC and DFID (RES-167-25-0251). As such the work has benefited greatly at all stages from the expertise and close cooperation of the other members of the team, Cecile Jackson and Nitya Rao. We are especially thankful to the hard-working efforts of our fieldwork manager, Matthew Osborne, and our local teams, led by Dr Biswarupa Gosh, Dr Pradip K. Sen, and Dr Anup K. Mishra in Uttar Pradesh, and Dr R. Naagarajan in Tamil Nadu, both under the guidance of Prof. Amaresh Dubey, from the Jawaharlal Nehru University, New Delhi. We are also grateful for helpful comments received from seminar participants at FASID, Tokyo, Tokyo Institute of Technology and the Economic Science Association meeting, Melbourne, 2010.
} 
create a contrast with the baseline in which resources can be hidden), and control of the allocation (to measure whether inducing autonomy experimentally through transferring agency matters for male and female contributions).

Generally, we find large-scale and robust evidence of inefficiency and the hiding of assets when this is possible. Men invest more and are more generous to their partners. Women are more willing to invest in a common pool when their income is earned through working and when assets are publicly observable. Regarding the focus of our paper, we find continuing significant differences between North and South and we find relatively little evidence that urban living is associated with changes in the nature of marital behaviour. There are some differences between response to treatment (e.g. female contributions respond to endowments being public only in the South, and male investment to male control of the allocation only in the North) but the key and striking difference between the North and the South is that in both rural and urban sites in the former region household efficiency is considerably greater than in the latter, which does on the face of it suggest a tradeoff between autonomy and efficiency.

\section{Background: India's North-South divide in female autonomy}

Although in a context of overall low female autonomy (compared to much of the rest of the world), a North-South divide has often been remarked on that shows in the northern and north-western parts of India having both distinct kinship systems and demographic regimes, including adverse-to-females sex ratios, that are consistent with less female say in household decisions, mobility and entitlement to resources than in the southern and south-eastern parts of the country (Sopher 1980; Miller 1981; Dyson and Moore 1983; Jejeebhoy 2001; Jejeebhoy and Sathar 2001; Agnihotri et al. 2002). The most influential characterisation of the northern and southern kinship systems in terms of their implications for female autonomy and demographic outcomes is that of Dyson and Moore (1983). For this purpose, they make use of an authoritative review of the ethnographic literature for India until about 1950, which focuses on kinship; and the extent of women's autonomy - defined as their 'decision-making ability with regard to personal affairs,' which include the affairs of one's intimates, and with access to information singled out for explicit mention as a component of decision-making ability (ibid.: 45) - is inferred from the nature of the kinship system.'

Thus the northern kinship system is characterised as favouring the internal cohesion of patrilineally related groups of males that resolve tensions/forge alliances with other such groups through the simultaneous and uni-directional transfer of resources (dowry) and female virgins: upon marriage, women leave their natal kinship network to join that of their husbands, after which their movements and sexuality are strictly controlled. By contrast, the southern kinship system is said to rely on the reciprocal exchange of women between groups and 
favours cross-cousin, village-endogamous marriage, so married women do not tend to stray far from their blood relatives. In this depiction of it, the northern compared to the southern kinship system is obviously responsible for lower female mobility and exposure to the outside world, and plausibly for lower female labour force participation, higher fertility, higher femaleto-male infant and child mortality (and therefore worse overall sex ratios), and less female say in household and personal decisions and entitlement to household resources (Sopher 1980; Miller 1981; Dyson and Moore 1983; Jejeebhoy and Sathar 2001).

For reasons that are slightly suspect (since they acknowledge the potential ultimate primacy of economic factors), Dyson and Moore have come to be associated with a school of thought that favours a cultural over an economic explanation for India's North-South divide in female autonomy. Others have emphasised the agro-ecological determinants of female economic worth, specifically the higher demand for female labour in wet-rice than in wheat growing areas, which would lead to a lower valuation of women in the North (Bardhan 1974; Miller 1981; Miller 1984). Whatever the historical veracity of that view, it could not explain presentday regional variation in gender discrimination patterns other than through a lingering persistence in culture, which argues for the more immediate usefulness of the cultural explanation.ii

Yet others, while not disputing that kinship systems critically influence female autonomy, doubt that Dyson and Moore's classification of Indian states accordingly, based as it is on ethnographies no later than the first half of the twentieth century, continues to be valid today (Rahman and Rao 2004). Using a survey administered in 1995 among 800 married women (in total) in the southern state of Karnataka and the northern state of Uttar Pradesh, both labelled without reservation by Dyson and Moore as typifying respectively the southern and northern kinship systems, Rahman and Rao find that female autonomy is worse in some respects in the North (influence over decisions about fertility and children's health and education) but better in others (expenditure decisions). Crucially, they find that the average distance between a wife's natal and current homes is not significantly different between the two states. In other words, they cast doubt on both parts of Dyson and Moore's (composite) thesis: that female autonomy is higher in the South, and that this is due to the continued relative nearness of the natal kinship network.

Rahman and Rao's (2004) study uses purposively selected districts, five in Karnataka and five in Uttar Pradesh, and is not designed to be representative for those states, let alone for 'the' South and 'the' North of India. Their findings are better taken as a reminder that the Dyson-Moore classification is based on ideal types and will not be universally corroborated rather than as evidence for its being out of date. Indeed, another study, using a very similar questionnaire, and a larger sample, based on fieldwork carried out a year before that of the Rahman-Rao study, again for the northern state of Uttar Pradesh and this time for the southern state of Tamil Nadu, found female autonomy to be considerably better in all key 
respects in the latter state: iii "A clear regional divide, net of individual and household characteristics is evident in almost every index of autonomy: decision-making authority, mobility, access to and control over economic resources, and, to a lesser extent, freedom from threat by husbands. Women in Tamil Nadu experience far greater autonomy than women in [...] Uttar Pradesh." (Jejeebhoy and Sathar 2001: 708). Our sites are purposively selected, in these same two states, in order to capture the North-South divide sketched above, but in the light of the contradicting findings from recent studies, site selection clearly needs to be validated, which we do using survey data, very similar in kind to those Rahman and Rao (2004) use, on the extent of female autonomy in a number of key respects. Our reasoning here is simply that we can only hope to shed light on the regional contrast we are interested in using experimental methods when we can be confident that we have captured the NorthSouth divide using the more traditional questionnaire-based methods. In our view, while the survey data are used to validate our site selection, they are neither epistemologically superior nor inferior to the experimental data. ${ }^{\text {iv }}$

\section{Autonomy versus Efficiency.}

It is useful to outline a theoretical model in which autonomy and efficiency are potentially in conflict. Given the complexity of real household environments, we do not claim to be testing this theory, but it provides some further motivation for our experimental investigation. Suppose there are $n+1$ goods in the household, $x_{i} i=1, \ldots, n$. We write $u(x)$ as the continuous and quasi-concave utility function for the wife and $v(x)$ as the corresponding function for the husband, where $x$ is the vector of goods, with associated price vector, $p$. It is useful to think of $x_{0}$ as a purely private good consumed by the wife and $x_{1}$ as a purely private good for the husband. All other goods are in theory household goods, providing benefits to both partners. Though in practice some goods may be of direct value only to one person, they may be indirectly valued by the other partner for the benefits brought to their spouse. In other words, this formulation allows for household goods which are clearly jointly consumed (e.g. heating) and for other-regarding preferences. We assume that there is at least one household good that is always positively valued by both spouses. Total household expenditure is $\mathrm{y}$, which is the sum of three non-negative components: $y^{h}, y^{\dagger}$ and $y^{m}$ where $h, f$ and $m$ refer to household, female and male budgets respectively. The allocation of goods is decided in a two-stage game. In the first stage, husband and wife separately allocate their own budgets to maximize individual utility. Note that both parties can purchase any of the goods and total consumption is the sum of individual purchases, $x^{\dagger}$ and $x^{m}$. In the second stage the household chooses $x^{h}$ to maximize the weighted sum of individual utilities, $W(x) \lambda u(x)+(1-\lambda) v(x)(0<\lambda<1)$ subject to the constraints that $p x^{h} \leq y^{h}, x=x^{h}+x^{\dagger}+x^{m}$ and $0 \leq x^{h}$. Another way of representing this is that the household chooses $x$ subject to the constraints that $p x \leq y$ and $x \geq x^{f}+x^{m}$. Either way, it is as if the spending chosen by the individual partners can be topped up by the household but not reduced. Thus the first stage of the game provides constraints on the possible values of $x$ in the second stage and when allocating their individual budgets, both 
spouses anticipate this. The model is therefore a close relative of the separate spheres model proposed by Lundberg and Pollak, 1994. In their model, the solution to the household's resource allocation problem comes from the Nash bargaining solution, rather than maximizing $\mathrm{W}(\mathrm{x})$. The fallback positions in their model are provided by the solution to a non-cooperative game in which each spouse controls the allocation of resources to one (or more) household public goods. This game therefore corresponds to the first stage of our model albeit that in our model spouses can contribute to any and all household public goods. ${ }^{\vee}$ Because the individual budgets give the spouses some power over the way the house allocates its resources, they can be interpreted as measures of autonomy. When $y^{\dagger}=0$, the wife has zero autonomy over spending. More generally, a higher value of $y^{f}\left(y^{m}\right)$ for given $y$ indicates a higher level of autonomy for the wife (husband) in the household.

With regards to $x^{*}$, the equilibrium pattern of expenditure, there are two cases to consider: first the individual budgets may be sufficiently low that they place no restrictions on the value of $x$ in the second stage. In this case the equilibrium value of $x^{*}=x^{* *}$, where $x^{* *}$ is defined as the value of $x$ that maximizes $W(x)$ subject to $p x \leq y$. Since $x^{* *}$ is, by construction, Pareto efficient then $x^{*}$ is also Pareto efficient. In the second case, individual budgets and preferences are such that $x^{*} \neq x^{\star *}$ - i.e. the constraint, $x \geq x^{\dagger}+x^{m}$ is strictly binding. Now when $y^{m}=y^{\dagger}=0$, then clearly $x^{*}=x^{* *}$, the equilibrium is Pareto efficient. Conversely, Dubey (1986) shows that when $y^{m}+y^{\dagger}=y$, then $x^{*}$ is generically strictly Pareto inefficient. ${ }^{\text {vi }}$ Thus autonomy and efficiency are inversely related. ${ }^{\text {vii }}$

A key question is what factors determine $y^{\dagger}$ and $y^{m}$. Income received and how it is acquired, may be important variables, along with social norms, the claims of others in the household and measures of bargaining power such as proximity of relatives, legal rules on individual property and divorce (Anderson and Eswaran, 2009). The potential for income or assets to be hidden may also be influential, inasmuch as a spouse who can hide income may need to be given some control over its allocation in order to induce him or her to reveal it to the household. In our experimental treatments we manipulate some of these factors (see below), though it is not clear that deeply established practices in a marriage, such as the level of autonomy, can be easily manipulated in an experimental setting. In other words, our prime focus is on the geographical comparison.

\section{Design.}

Across the three sites we have five treatments in common which we introduce as follows:

1. Investment baseline. Both partners have endowments and can make investments. The pool is split equally after we add $50 \%$.

2. Female control - both subjects have endowments and can make investments, but the women control the allocation of the pool. 
3. Male control - as above, but with male control of the allocation.

4. Public endowments. As for the investment baseline, but with endowments revealed publicly.

5. Production with investment - in this treatment subjects earn their endowments, but can then invest in the pool in the same format as treatment 1.

In addition we use a female trust treatment, which has data for both northern (rural) India and the south, but not for the urban north. In this treatment, only men have endowments and the allocation of the pool is the responsibility of the wife. The endowment is twice the amount given to individuals in the other investment treatments.

In treatment 1 , the investment baseline treatment, each subject, i, separately and privately receives an endowment of $E_{i}=160$ Rupees. Each person then chooses an investment, $x_{i}$ from the set $\{0,40,80,120,160\}$. The investments of the 2 players are summed and multiplied by 1.5 and then each player receives half of the total.

In the female control treatment each subject separately and privately receives the same sum as in treatment 1 and makes an investment decision from the same choice set. The investments are summed and multiplied in the same manner, but then the wife chooses how much to allocate to each person in the household. This decision is made using the strategy method. That is, after choosing her own investment, for each possible investment by her husband, she must make a conditional allocation of the pool. Once the husband's actual investment is revealed, the allocation proceeds according to the conditional plan. Treatment 3 is the same, except it is the husband who controls the allocation and must produce a strategy for dividing the pool between the spouses.

In treatment 4, the private endowment is common knowledge. Otherwise this treatment is the same as treatment 1 . In all but treatment 4 , the private endowment $E_{i}$ is known only to individual i., whereas the common account and the final allocation from that account is always common knowledge. We told participants that,

The exact amount will vary between people, but you will receive something between 0 and 160 Rupees. [Show the envelope.] Your wives will each receive a similar envelope and they will each receive an amount of money between 0 and 160 Rupees. They don't know how much you have in your envelope and you won't be told how much they have in their envelopes. None of you will know what the others have.

In most treatments we did not reveal full information about each individual's endowment in order to mimic the typical household situation. Asymmetric information about individual resources and spending is a familiar and well-documented facet of household behaviour in many cultures (Pahl, 1990). Our own follow-up survey (see below) confirms its relevance for the samples in this experiment. Whether manipulating the information set alters behaviour however is not clear cut. Munro et al, 2007, find providing information about a partner's 
choices makes no difference to behaviour in an experiment conducted on UK couples. However in her experiment on Philippine households and their savings decisions, Ashraf, 2009 concludes that transparency affects male (but not female) behaviour. In what is probably the closest parallel to our research, Mani, 2008 uses 300 couples in rural Andhra Pradesh, recruited through an NGO that organises women's self-help groups. Players typically face 4 tasks including one baseline task where they must split 50 rupees between a high return and a low return account (with the share going to each spouse fixed) and another task in which subjects split 50 rupees between a high return investment that goes to the spouse's private account or a low return account that stays with the investor. She finds that the separated spouses typically invest $70 \%$ to $80 \%$ of their investment in the high paying account that goes to the partner. Crucially, she has a full information and private information variations which make little difference to the results.

It seems that the limited evidence available is mixed on the important issue of asymmetric information. It is worthwhile stressing that in our experiment the total surplus maximizer has no incentive to withhold contributions, even with asymmetric information, but of course players with different motives may wish to hide some or all of their endowment from their partner. This could be achieved by not placing some of the endowment in the common pool. However, because there are other motives for not investing which apply even if endowments are common knowledge, we cannot interpret all failures to invest as evidence of deceit. The clearest evidence of attempts to conceal resources is provided where the potential investor also controls the allocation (i.e. the wife in treatment 3). In this context we measure opportunism as the difference $E_{i}-x_{i}$ where $x_{i}$ is the investment made by player $i$ who has a strictly positive endowment, $E_{i}$, and is the allocator.

In treatment 5 subjects earn their endowments by assembling up to 8 matchboxes in a fixed time period. For each pair of matchboxes completed the experimenter's satisfaction subjects were paid 40 rupees. Thus subjects could earn 160 Rupees - the same endowment as in treatments 1-4. The sexes were segregated for the production tasks, meaning that as in treatments 1-3, the endowment was private knowledge. After completing the task, subjects faced the same investment problem as in treatment 1 . We include a production task, because there is evidence (e.g. Cherry et al, 2002) from other types of experiments that individuals have different attitudes to money that is presented as a gift from the experimenters and money that is earned. There are also theoretical perspectives why behaviour might be different in our context. If individuals have more control rights over money that is earned then a spouse may be more willing to invest it in the publicly observable pool.

The experiments took place on 5 consecutive days in 2009. In each site, five locations were selected. In the case of rural sites, these five locations were distinct villages. The villages had been pre-selected in the month leading up to the main fieldwork using local informants, data from the 2001 census, and prior visits by members of the research team. The major selection 
criteria were size (we needed to recruit 80 couples from each place), rural location and separation from the other sites (to limit the possibility of cross-contamination). The villages selected in Uttar Pradesh are between 10 and 40 kilometres away from central Varanasi. Typically, people are cultivators (they grow vegetables, cereals (mainly wheat), pulses, some rice) and daily wagers (commute to Varanasi or to nearby town or perform some services inside the village). In Tamil Nadu the villages selected were approximately 40-60 kilometres north from Coimbatore. Coconut plantations and poultry farms dominate local agriculture, and a large number of villagers, including women, work in towns in the garment, powerloom and hosiery industries. There is a high rate of female workforce participation.

For the urban location five wards out of 50 were randomly selected. Then within a ward, a named locality was selected that typically consisted of some 300 households on the criterion that we wanted lower income households. With the help of local corporators (the urban equivalents of the village pradhan (chief); as pradhans these are elected local representatives), lower-income parts of the wards were identified. The five urban localities selected were in three different U.P. assembly constituencies: Cantonment (Saketnagar, Lahartara), North (Sonarpura) and South (Khojwan, Nagawa). Livelihoods in these localities are very diverse but mainly consisting of various forms of self-employment in the informal sector, and daily wagers: very few are in regular salaried employment. Female labour force participation is high in these areas. Caste composition is skewed towards scheduled castes (SC), the next largest group is Other Backward Castes (OBC), and then there are very few forward castes members.

In each location, prior visits gave us a list of possibly willing households. From that list we randomly selected 90 households per village, 10 of which were assigned to the reserve list (again randomly) to be used in the case of no-shows.

The actual experimenters were 12 ( 6 female and 6 male) local researchers recruited through the advice of local partners from a local University. Most of them had some background in Sociology or Economics. Some of them had experience with the implementation of household surveys. All of them were able to communicate effectively with the experimental participants in their local language, and to adequately understand the instructions they received in English. The experimenters received five days of training from three UK-based researchers from the project. The first day of training was used for explaining the principles of how to run experiments (what to do and what not to do with examples) and presenting all the treatments to be played in the region. On days 2 and 3 experimenters practised in the local language (and sometimes in English so that the team leaders could understand). On day 4 we ran a pilot using a small sample of subjects. The fifth day of training was used to give individual and collective feedback on the pilot, to explain the logistics for the game days and to distribute the material needed for the first 5 game days. ${ }^{\text {viii }}$ 
The experiments used scripts translated into the local language and then back-translated into English. Each experimenter was also used to compare the English and the translated versions of 2 or 3 treatments. Discrepancies were then corrected by all experimenters during the training in the local language version. Across the 15 locations, venues were mixed and included middle and secondary schools as well as farm building with concrete floors and specially erected tents.

The schedule for the 5 game days was as follows: 4 treatments in the morning and 4 treatments in the afternoon. Secrecy was ensured by calling one household at a time and separating each person, with the husband going to one location with one researcher and each of the wives going separately to another location with other researchers. Each spouse removed from their envelope what they wanted to keep for themselves, with the remainder left for the common account. A helper collected their envelopes and recorded the decisions. For the production task, the sexes were segregated and subjects practised production before engaging in it for real.

\section{Results.}

We thus have an experimental design that tests for efficiency, and the impact on efficiency of whether endowments are earned, whether endowments are public, and the spouse who controls the allocation of the common pool. As explained above, these are all avenues through which the autonomy of individual spouses could lead to household inefficiency, as well as respects in which our northern and southern sites could differ. Before considering the experimental results, we begin by setting out some basic facts about our sample in Table 1. We then consider the survey data and compare the attitudes and lifestyles within our sample to those reported in Rahman and Rao, 2004, and Jejeebhoy and Sathar, 2001, which reach contradictory conclusions about the continued relevance of the Dyson and Moore thesis. We have two overlapping aims in doing this. The first is to validate our site selection, i.e. to check whether we have captured the north-south contrast using very similar methods to those used in the two studies just referred to. The second aim is to establish whether the key avenues we focus on through which household inefficiency could come about - individually earned and controlled resources, the possibility to conceal some of these, separate spheres of decisionmaking - are each different across the sites in the way we expect them to be different.

Interviewing a sample of 800 wives, Rahman and Rao, 2004, find a series of significant differences between the practices of conjugality in rural Uttar Pradesh and Karnataka, which they conclude does not point to systematic extra subordination of women in the north compared to the south. By contrast, Jejeebhoy and Sathar, 2001, use very similar interviews of 1,842 women in sites in rural Uttar Pradesh and Tamil Nadu (the two states in which our sites are also located), and conclude that female autonomy is higher in their southern sites in almost all respects considered. For more details on these two studies, see the background section above. The tables which follow summarise our evidence on similar issues, drawn in 
our case from separate interviews with both husbands and wives. ${ }^{i x}$ To a large degree we find very similar patterns in our rural and urban Uttar Pradesh locations, which in turn are typically very different to the average household in Tamil Nadu. Table 2, for instance, illustrates the differences in endogamy between north and south, which Dyson and Moore hold to be at the root of the regional divide in female autonomy. Marrying relatives is almost unheard of in our Uttar Pradesh samples, but common in Tamil Nadu. Wives are highly unlikely to be living in the maternal home in the north, whereas in both regions around 2/3 of men report that they are living in a household with their parents. Dowries were lower in the south compared to the north. ${ }^{x}$ The last two rows of data in Table 2 report answers to questions about 'typical community practices.' Although spouses rarely split up in any of these sites, if they do it is relatively common for the wife to be allocated property (e.g. a house) upon divorce in Tamil Nadu, but almost unheard of in both urban and rural Uttar Pradesh. It is also notable that according to respondents in Tamil Nadu, prior ownership of property assets have little relevance for their allocation at divorce. For more mobile assets, such as cash and jewellery, allocation at divorce follows more closely the pattern of original ownership. For instance, with gold and jewellery, the percentage of respondents who state that wives would normally get jewellery on divorce is $18 \%$ if jewellery was owned by the husband at time of marriage and $90.2 \%$ if it was the wife's property. For gold jewellery bought after marriage the gap is only slightly less stark - the corresponding figures are $28 \%$ and $85 \%$.

\begin{tabular}{lcccc}
\hline \multicolumn{5}{c}{ TABLE 1. Background facts about the samples } \\
\hline & $\begin{array}{l}\text { Uttar } \\
\text { Pradesh } \\
\text { (Rural) }\end{array}$ & $\begin{array}{l}\text { Uttar } \\
\text { Pradesh } \\
\text { (Urban) }\end{array}$ & $\begin{array}{l}\text { Tamil } \\
\text { Nadu } \\
\text { (Rural) }\end{array}$ & $\begin{array}{l}\text { Rural north } \\
\text { versus rural } \\
\text { south (p- } \\
\text { values) }\end{array}$ \\
\hline Experiment sample size & 400 & 400 & 400 & - \\
Household survey sample size & 393 & 376 & 400 & - \\
Mean age (wife) & 41.8 & 39.7 & 39.9 & 0.040 \\
Mean age (husband) & 46.1 & 44.1 & 47.3 & 0.260 \\
Mean years married & 27.9 & 23.9 & 21.6 & 0.000 \\
Mean household size & 7.31 & 6.10 & 3.70 & 0.000 \\
Mean no. of children & 2.66 & 2.07 & 0.81 & 0.000 \\
\% working in agriculture (husbands) & 26.3 & 3.7 & 50.5 & 0.000 \\
Mean wife's annual income (Rupees) & 2787 & 4507 & 12618 & 0.000 \\
Mean husband's annual income (Rupees) & 44976 & 33848 & 40384 & 0.040 \\
Median Gross household wealth (Rupees) & 103308 & 92729 & 141450 & 0.000 \\
& & & & \\
\hline
\end{tabular}

Notes:

1. $p$-values are for a two-sided Mann Whitney test, except for the \% working in agriculture measures where we use a Fisher's exact test.

2. For income we use the figure reported by each person separately. For wealth, only husbands faced the relevant set of questions. It is worth noting that median income for women is zero in both northern samples. In the south median female income is 2000 Rupees per annum.

Table 3 provides some measures of perceived autonomy as reported by the women in our sample. Consider first the allocation of time. In both northern locations, unpaid work is the norm. In the south, unpaid work, including childcare is still the largest category (34.5\%), but working on her own business $(22.8 \%)$ and doing paid agricultural work (18.8\%) are relatively 
common. In fact the proportion of women doing either agricultural or non-agricultural paid work is similar across all three locations. Tamil Nadu differs from the northern rural areas in the percentage of women who work in their own business in the south and in the higher percentage of southern women who work on the family farm. Similarly, women report less say in decisions that concern their ability to operate independently outside the home, earn private income and purchase private goods in the north. One bit of evidence on autonomy is conflicting, in that women are more likely to own their own assets in Uttar Pradesh. (Separate ownership of land was rare in both north and south, with about $4 \%$ of women in each location reporting they had land under their own name.) However, it could well be that this reflects the larger dowry paid in the north, which even if it is counted as part of a woman's own assets, is highly unlikely to correspond with assets that she can dispose of as she sees fit.

\begin{tabular}{|c|c|c|c|c|}
\hline \multicolumn{5}{|c|}{ TABLE 2. Kinship and cultural practices } \\
\hline & $\begin{array}{l}\text { Uttar } \\
\text { Pradesh } \\
\text { (Rural) }\end{array}$ & $\begin{array}{l}\text { Uttar } \\
\text { Pradesh } \\
\text { (Urban) }\end{array}$ & $\begin{array}{l}\text { Tamil } \\
\text { Nadu } \\
\text { (Rural) }\end{array}$ & $\begin{array}{l}\text { Rural north versus } \\
\text { rural south } \\
\text { (p-value) }\end{array}$ \\
\hline Marry relatives (\%) & 0.5 & 0.3 & 42.8 & 0.000 \\
\hline Scheduled caste (\%) & 34.8 & 51.6 & 35.3 & 0.882 \\
\hline Living with parents (women, \%) & 0.0 & 2.9 & 21.0 & 0.000 \\
\hline Living with parents (men, \%) & 70.3 & 77.0 & 64.0 & 0.059 \\
\hline Average dowry paid (Rupees)* & 3192 & 4174 & 2336 & 0.000 \\
\hline $\begin{array}{l}\text { What happens upon divorce to house } \\
\text { acquired jointly during marriage (\% } \\
\text { indicating house goes to wife) }\end{array}$ & 0.77 & 0.80 & 44.0 & 0.000 \\
\hline $\begin{array}{l}\text { What happens upon divorce to house } \\
\text { husband brought to marriage (\% indicating } \\
\text { house goes to wife) }\end{array}$ & 0.00 & 0.27 & 40.5 & 0.000 \\
\hline
\end{tabular}

TABLE 3. Indicators of Autonomy

\begin{tabular}{|c|c|c|c|c|}
\hline & $\begin{array}{l}\text { Uttar } \\
\text { Pradesh } \\
\text { (Rural) }\end{array}$ & $\begin{array}{l}\text { Uttar } \\
\text { Pradesh } \\
\text { (Urban) }\end{array}$ & $\begin{array}{l}\text { Tamil } \\
\text { Nadu } \\
\text { (Rural) }\end{array}$ & $\begin{array}{l}\text { Rural north } \\
\text { versus rural } \\
\text { south (Fisher's } \\
\text { exact, p-value) }\end{array}$ \\
\hline Wife spends most of the day on unpaid work (\%) & 50.90 & 62.50 & 34.50 & 0.000 \\
\hline $\begin{array}{l}\text { Wife is primary decision-maker about if she should } \\
\text { work outside the home (\%) }\end{array}$ & 1.28 & 0.53 & 30.75 & 0.000 \\
\hline $\begin{array}{l}\text { Wife need not consult husband about purchase of } \\
\text { new sari (\%) }\end{array}$ & 48.08 & 46.28 & 73.75 & 0.000 \\
\hline Wife has property (including jewellery) of her own (\%) & 64.63 & 79.73 & 23.25 & 0.000 \\
\hline
\end{tabular}

When asked what major change women would like to make to their lives, $78 \%$ of women in the south reported no change, compared to $36 \%$ in rural Uttar Pradesh and $31 \%$ in the urban sample. Of the dissatisfied, by far the largest desire was for more time for paid work or own business, which could partly be explained by the fact that wives of migrant or wage workers in 
Varanasi are often managing the daily running of the household farm but not involved in the marketing of its produce, so that they have neither time left nor income of their own.

We asked both spouses who was the person primarily responsible for making decisions in a variety of areas. ${ }^{\text {xi }}$ Summary answers are given in Table 4, where as in Rahman and Rao, 2004, we aggregate across several questions. There is some difference between urban and rural north, but the biggest gap is between north and south: women generally answered that they were the primary decision-maker more often in Tamil Nadu than in Uttar Pradesh. Men concurred with this view, but were more likely to nominate themselves as the main decisionmaker in the south. Whether we take the men or the women's view our results are in contrast to those in Rahman and Rao 2004 (e.g. their Table 3) and more in line with the earlier conclusions of Dyson and Moore echoed in Jejeebhoy and Sathar 2001. The differences across states in the results of individual questions are always in line with the pattern of the overall indices. In particular, we find women have significantly more say on major household purchases or general expenditure of income in the south compared to the north.

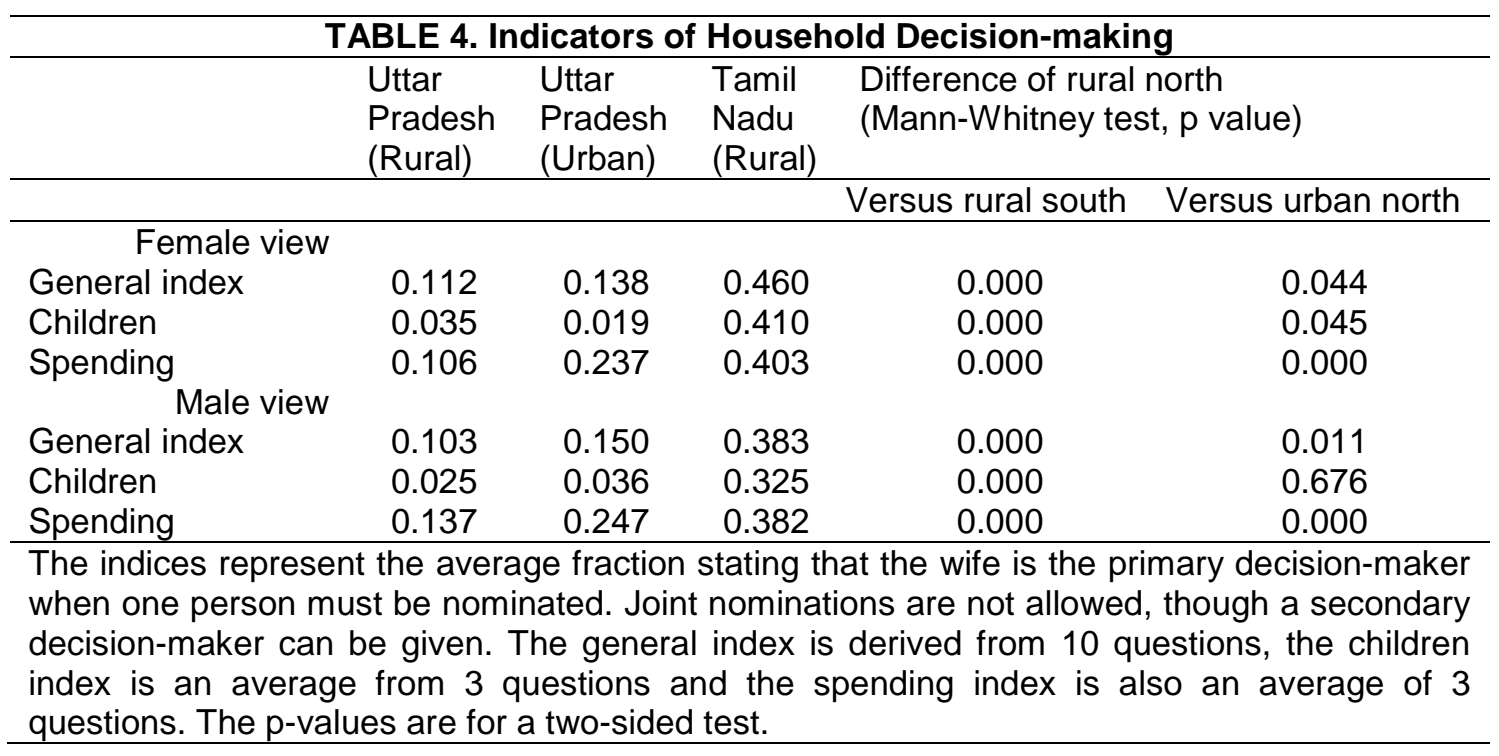

In general in answer to our questions about various decisions under $10 \%$ of women in any community reported that they were neither the first nor the second decision-maker. Notable exceptions to this occur in the questions of whether a wife should work outside the home and to whom to marry children. In the first case, 11 and $17 \%$ of husbands in urban and rural Uttar Pradesh respectively state that their wives are not the primary or secondary decision-maker. In Tamil Nadu the corresponding percentage is 4 . In the second case, the percentages of women with no say are 14, 19 and 25 in urban Uttar Pradesh, rural Uttar Pradesh and Tamil Nadu. (The figures for the two rural sites yield $p=0.04$ for a Fisher's exact test of their equality.) Usually it is a child who acts as the co-decision maker though we have no information about whether this is the child facing marriage. 
Table 5 produces some general figures on trust and satisfaction. Overwhelmingly the men and women of Tamil Nadu are more satisfied with their current allocation of time. Amongst all regions, dissatisfied women and men sought more time for paid activities. For women the major obstacles to their goals were unsurprisingly finance and childcare responsibilities. For men, lack of finance dominated the explanations. We asked men and women what portion of a windfall they would hide from their partner and what portion they would expect their partner to hide? The figures shown amalgamate the responses of subjects who declared that at least half the sum would be hidden. This was relatively infrequent amongst both men and women in the north, but significantly higher in the south. In general, spouses' expectations about their partners were close to what their partners declared in the north. The figures in the table suggest some (insignificant) tendency for men to plan to hide more than their wives were expecting and for wives to hide less than anticipated by their partners. However, when we look at the full range of figures this difference disappears. For instance $2 / 3$ of men in Uttar Pradesh expect their partners to hide nothing, whereas in fact $50.8 \%$ of urban wives and $42.2 \%$ of rural wives state that they would hide nothing. The gap between expectations and plans is starker in the south, where $50 \%$ of men would hide at least half their windfall, but only $22.8 \%$ of women predicted such behaviour. Women were less likely to hide at least half, compared to the expectations of their husbands. Thus in short, men and women in the north were more trusting and trustworthy towards their partners, compared to subjects from the south, and their expectations were more accurate.

\begin{tabular}{|c|c|c|c|c|}
\hline \multicolumn{5}{|c|}{ TABLE 5. Indicators of Trust and Satisfaction } \\
\hline & $\begin{array}{l}\text { Uttar } \\
\text { Pradesh } \\
\text { (Rural) } \\
\end{array}$ & $\begin{array}{l}\text { Uttar } \\
\text { Pradesh } \\
\text { (Urban) }\end{array}$ & $\begin{array}{l}\text { Tamil } \\
\text { Nadu } \\
\text { (Rural) }\end{array}$ & $\begin{array}{l}\text { Rural north versus } \\
\text { rural south (Fisher's } \\
\text { exact test, p-value) }\end{array}$ \\
\hline \multicolumn{5}{|l|}{ Female view } \\
\hline Nothing I wish to change (\%) & 47.1 & 49.5 & 87.8 & 0.000 \\
\hline Hide at least half a windfall (\%) & 14.3 & 5.6 & 39.8 & 0.000 \\
\hline Partner would hide at least half a windfall (\%) & 11.9 & 8.7 & 22.8 & 0.000 \\
\hline \multicolumn{5}{|c|}{ Male view } \\
\hline Nothing I wish to change & 35.9 & 31.5 & 78.0 & 0.000 \\
\hline Hide at least half a windfall (\%) & 14.5 & 10.9 & 50.0 & 0.000 \\
\hline Partner would hide at least half a windfall (\%) & 15.0 & 6.9 & 49.3 & 0.000 \\
\hline
\end{tabular}

Table 6 summarises normative beliefs about appropriate behaviour. The table shows responses to questions where subjects were asked directly to agree or disagree with statements about appropriate household behaviour. As with the other responses, there are clear differences between north and south, but it would be wrong to categorise these along a one dimensional scale of conservatism (where for the sake of the table we define this ambiguous concept as agreement with the statements). Women and men in the northern state were significantly more likely to agree that a husband's permission was required for a woman to work outside the home and that a woman should follow the instructions of her elders. However, women and men in Tamil Nadu were more likely to believe that the man should have the last word and that priority should be given to boys in education. Between 
question variation in percentages is similar for men and women, but husbands were significantly more likely to believe in obedience to elders. Significantly, men in the north were much more likely to agree that a woman's wages should be handed over to him, both compared to their wives and to men in the south.

In a second set of questions, details of which are omitted here, subjects were asked to indicate their beliefs about what most people in their community would think. We asked specifically about potential occasions when it was generally viewed as acceptable for men to beat wives. On the whole, men and women gave similar answers, with couples in the northern state significantly more likely to agree that a beating was seen as usual when, for instance, a wife neglected the cleaning, was suspected of an affair or went out without telling her husband.

TABLE 6. Indicators of normative beliefs

Uttar Uttar Tamil Rural

Pradesh Pradesh Nadu north

(Rural) (Urban) (Rural) versus

Female view (\% agree or strongly agree)

1. A man should have the final say in all family matters

2. If a woman works she should give her money to her husband

3. A woman needs her husband's permission to do paid $\begin{array}{llll}94.06 & 96.53 & 75.50 & 0.000\end{array}$ work

4. It is a woman's job mainly to take care of the home and $\begin{array}{llll}28.24 & 23.92 & 66.00 & 0.000\end{array}$ cook for her family

$\begin{array}{lllll}\text { 5. A woman should always follow instructions by elders } & 75.13 & 70.93 & 57.75 & 0.000\end{array}$ (particularly by her in-laws) whether she likes them or not.

6. A wife should tolerate being beaten in order to keep her $\begin{array}{llll}35.62 & 39.20 & 54.25 & 0.000\end{array}$ family together

$\begin{array}{llllll}\text { 7. Boys should get priority when family cannot send all } & 9.71 & 7.20 & 46.25 & 0.000\end{array}$ children to school

8. It is better to let the wife handle the money of the house $\begin{array}{llll}87.96 & 96.53 & 73.00 & 0.000\end{array}$ Male view (\% agree or strongly agree)

$\begin{array}{llllll}\text { 1. A man should have the final say in all family matters } & 56.89 & 27.35 & 76.00 & 0.000\end{array}$

$\begin{array}{llllll}2 . & \text { If a woman works she should give her money to her } & 62.24 & 62.20 & 57.00 & 0.148\end{array}$ husband

3. A woman needs her husband's permission to do paid $\quad 83.16 \quad 86.60 \quad 69.00 \quad 0.000$ work

4. It is a woman's job mainly to take care of the home and $\begin{array}{llll}41.65 & 37.37 & 55.75 & 0.000\end{array}$ cook for her family

$\begin{array}{lllll}\text { 5. A woman should always follow instructions by elders } & 93.01 & 90.59 & 73.00 & 0.000\end{array}$ (particularly by her in-laws) whether she likes them or not.

6. A wife should tolerate being beaten in order to keep her $70.39 \quad 69.44 \quad 49.00 \quad 0.000$ family together

$\begin{array}{llllll}\text { 7. Boys should get priority when family cannot send all } & 32.12 & 27.88 & 53.25 & 0.000\end{array}$ children to school

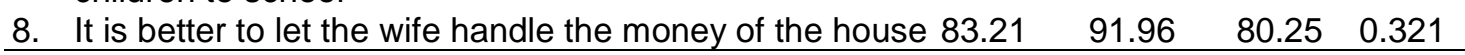

The last table in this section examines the extent to which wives and husbands gave similar answers. Take the 'congruence on primary decision-maker' entries as an example. If the 
figure in a column was 1 this would mean that across 9 questions about who was the primary decision-maker, all couples in the sample agreed in every single instance. A figure of 0 would mean that all couples disagreed in their responses on all 9 questions. In practice, congruence on primary decision-maker was high in Uttar Pradesh and significantly lower in Tamil Nadu. In fact in all cases, the figure for Tamil Nadu is significantly lower than that for rural Uttar Pradesh. ${ }^{\text {xil }}$ We also asked both spouses questions about their partner's income. Approximately $86 \%$ of men in rural Uttar Pradesh gave a figure for the wife's income that was within 5,000 Rupees of the figure she gave. For Tamil Nadu the corresponding statistic was only $29.8 \%$. Agreement on husband's income was lower in the northern state, but still significantly higher than the figure for Tamil Nadu.

\begin{tabular}{|c|c|c|c|c|}
\hline \multicolumn{5}{|c|}{ TABLE 7. Indicators of congruence in attitudes and beliefs } \\
\hline & $\begin{array}{l}\text { Uttar } \\
\text { Pradesh } \\
\text { (Rural) }\end{array}$ & $\begin{array}{l}\text { Uttar } \\
\text { Pradesh } \\
\text { (Urban) }\end{array}$ & $\begin{array}{l}\text { Tamil } \\
\text { Nadu } \\
\text { (Rural) }\end{array}$ & $\begin{array}{l}\text { Rural north } \\
\text { versus rural } \\
\text { south }(p- \\
\text { values) }\end{array}$ \\
\hline Congruence on primary decision-maker & 315 & 809 & 1 & 0.000 \\
\hline & & & & \\
\hline & & & & \\
\hline Con & 9 & 7 & 9 & 0.000 \\
\hline $\begin{array}{l}\text { on wife's annual income } \\
\text { 000 Rupees) }\end{array}$ & & & & 00 \\
\hline $\begin{array}{l}\text { Agreement on husband's annual income (\% } \\
\text { within 5,000 Rupees) }\end{array}$ & 48.09 & 59.15 & 34.25 & 0.000 \\
\hline \multirow{2}{*}{\multicolumn{5}{|c|}{$\begin{array}{l}\text { Notes: } \\
\text { 1. The congruence figures are fractions of average congruence across groups of related } \\
\text { questions ( } 19 \text { prime responsibility, } 9 \text { primary decision-maker, } 8 \text { normative beliefs and } 7 \\
\text { community norms). For a household, a figure of } 1 \text { would represent that both partners } \\
\text { gave the same responses on all relevant questions; a figure of } 0 \text { represents disagreement } \\
\text { on all responses. }\end{array}$}} \\
\hline & & & & $\begin{array}{l}\text { 2. p-values are for a two-sided Mann Whitney test, except for the income questions where a } \\
\text { 2-sided Fisher's exact test is employed. } \\
\text { 3. The agreement on wife's income variable is for women reporting a non-zero income. } \\
\text { Agreement is more common once zero-earning women are included, but the North-South } \\
\text { gap remains large and significant. }\end{array}$ \\
\hline
\end{tabular}

This section compared the results of our survey to that in Rahman and Rao, 2004, and Jejeebhoy and Sathar, 2001. Contrary to the former and in line with the latter, we find significant differences between north and south and these distinctions are present whether we look at statements by female respondents or at the responses made by men. In general, urban and rural northern samples are very similar. Men in the north have more decisionmaking say and women have less autonomy compared to the south. Of specific relevance for our study, we find that the key respects in which greater autonomy of individual spouses could translate into inefficiency all differ across sites in the way we would expect. First, women are in a position to secure their own resources more frequently in the south: they earn their own income more often, and earn a higher income on average than in the north. Second, spouses hide their resources much more frequently from each other in the south. Third, almost invariably and in a large number of spheres, women are more frequently the primary 
decision-maker in the south than in the north. Rahman and Rao find some evidence that women in the north have relatively more say in particular decisions. We do not find supporting evidence for this. The impression that spouses act much more like a unity, if an enforced unity, in the north is reinforced by the strikingly larger congruence of views on the identity of the primary decision-maker and on normative beliefs, as well as by the much more accurate knowledge of the size of one's spouse's income and prediction of what one's spouse would do with a windfall.

With both spouses controlling resources independently, inefficiency becomes a possibility, a fortiori so when spouses do not fully observe each other's exercising that control. Independent and partly unobserved command of resources is present in each of our sites, but to a much greater degree in the south, which therefore has more scope for inefficiency. We next consider the extent to which inefficiency in fact differs across our sites.

\section{Experimental Results.}

As we noted above, in all 10 treatments were conducted in each sites with 40 couples in each cell. Below we concentrate on the 5 treatments common to all three sites, though from time to time we bring in additional material from comparisons that are incomplete across locations, such as the female trust treatment, which has data for both northern (rural) India and the south. Table 8 provides a useful starting point, showing mean rates of investment by women across treatments and sites.

\begin{tabular}{|c|c|c|c|c|}
\hline \multicolumn{5}{|c|}{ Table 8. Mean fraction of Female Endowment Invested. } \\
\hline & $\begin{array}{c}\text { Uttar Pradesh, } \\
\text { Urban }\end{array}$ & $\begin{array}{c}\text { Uttar Pradesh, } \\
\text { Rural }\end{array}$ & Tamil Nadu & All sites. \\
\hline Investment baseline & $0.731^{\star * *}$ & 0.494 & 0.500 & 0.575 \\
\hline Female control & 0.531 & $0.538^{*}$ & 0.456 & $0.508^{\star \star}$ \\
\hline Male control & $0.656^{* * *}$ & 0.519 & 0.444 & 0.540 \\
\hline Female trust & - & $0.697^{\star \star}$ & 0.578 & $0.638^{*}$ \\
\hline Public endowments & $0.775^{\star \star \star}$ & $0.569^{\star * \star}$ & 0.381 & 0.575 \\
\hline Production with investment & $0.775^{\star * *}$ & $0.717^{* * *}$ & 0.481 & $0.658^{* *}$ \\
\hline Average & $0.694^{* \star *}$ & $0.589^{\star \star \star}$ & 0.473 & 0.579 \\
\hline \multicolumn{5}{|c|}{$\begin{array}{l}\text { In the 'Uttar Pradesh' columns asterisks indicate statistical difference to corresponding } \\
\text { treatment in Tamil Nadu, using a Mann-Whitney test. In the 'All sites' column, asterisks } \\
\text { indicate statistical difference to the investment baseline treatment. } \\
{ }^{* * *} \text { significant at } 1 \% \text { level, }{ }^{* *} \text { significant at } 5 \% \text { level, * significant at } 10 \% \text { level, } 2 \text { tailed test. }\end{array}$} \\
\hline
\end{tabular}


The geographical pattern for men (see Table 9) is broadly similar to that for women:

Table 9. Mean fraction of Male Endowment Invested.

\begin{tabular}{|c|c|c|c|c|}
\hline & $\begin{array}{c}\text { Uttar Prade } \\
\text { Urban }\end{array}$ & $\begin{array}{c}\text { Uttar Pradesh, } \\
\text { Rural }\end{array}$ & Tamil Nadu & All sites. \\
\hline Investment baseline & $0.731^{* * *}$ & $0.681^{*}$ & 0.581 & 0.664 \\
\hline Female control & 0.544 & 0.606 & 0.513 & $0.554^{* * *}$ \\
\hline Male control & 0.625 & 0.606 & 0.556 & $0.596^{* *}$ \\
\hline Public endowments & $0.706^{\star * *}$ & $0.600^{*}$ & 0.488 & $0.598^{* *}$ \\
\hline Production with investment & $0.710^{*}$ & $0.717^{\star *}$ & 0.604 & 0.677 \\
\hline Average & $0.663^{* * *}$ & $0.642^{* * *}$ & 0.548 & 0.618 \\
\hline Male-female & - & $\star \star * *$ & *** & *** \\
\hline \multicolumn{5}{|c|}{$\begin{array}{l}\text { In the 'Uttar Pradesh' columns asterisks indicate statistical difference to corresponding } \\
\text { treatment in Tamil Nadu, using a Mann-Whitney test. In the 'All sites' column, asterisks } \\
\text { indicate statistical difference to the investment baseline treatment. In the 'male-female' row, } \\
\text { asterisks indicate statistical difference to the corresponding female figure and omits the } \\
\text { incomplete 'Female trust' treatment from the comparison. }{ }^{* * *} \text { significant at } 1 \% \text { level, ** } \\
\text { significant at } 5 \% \text { level, * significant at } 10 \% \text { level, } 2 \text { tailed tests. }\end{array}$} \\
\hline
\end{tabular}

Figure 1 provides a snapshot of the data across the sites and genders for the 5 universal treatments.

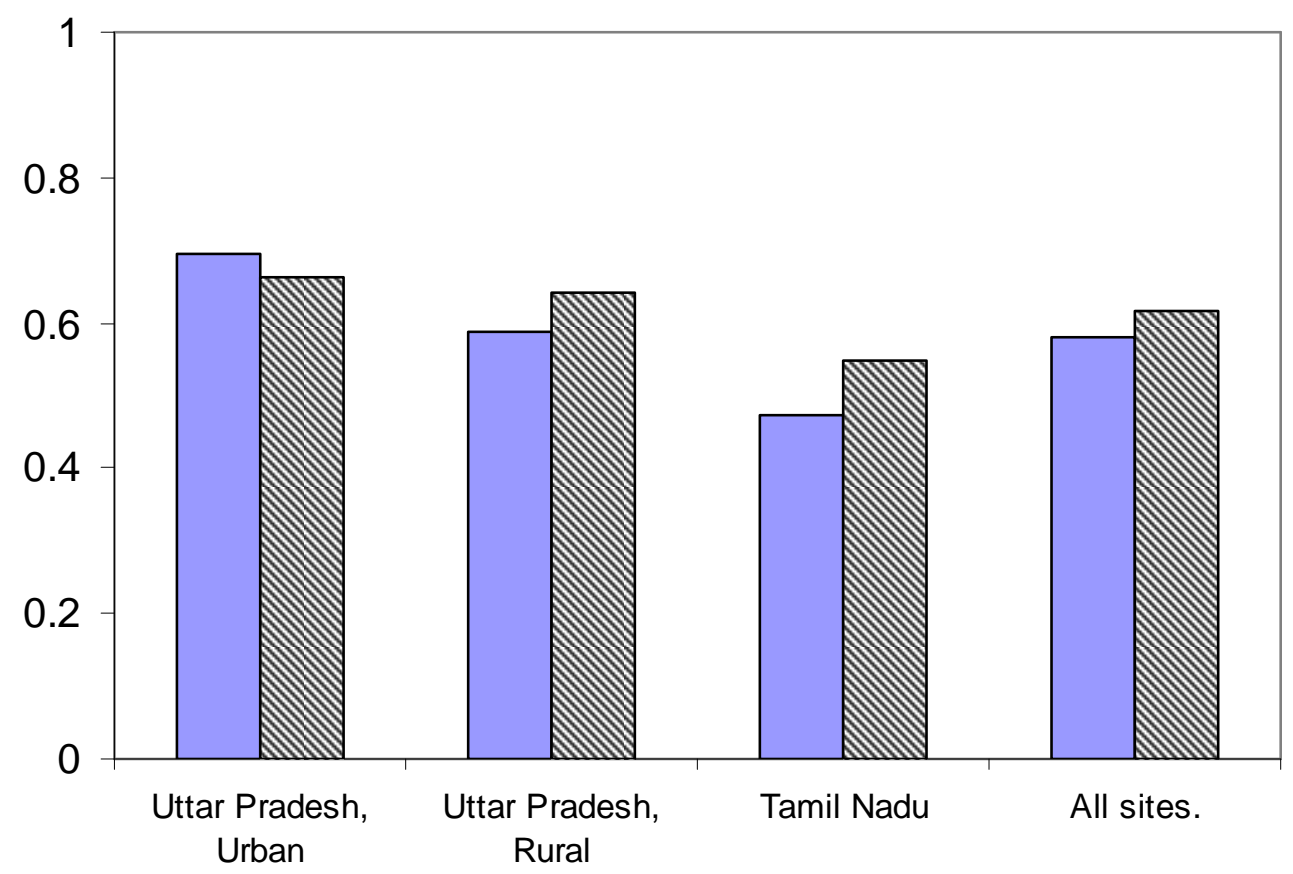

$\square$ Female Investment $\mathbb{\Delta}$ Male Investment

Figure 1. Average Investment Rates by Site and Gender. 
There are seven basic messages in the data presented in the figure and these two tables, which are robust to the introduction of controls from the household survey data.

1. First, across all sites and treatments, men and women do not invest all of their endowments - surplus is not maximized outside of a small number of households. In the south only one household invests all its endowment. In the rural north, around $7 \%$ of households invest all and in the urban north approximately $15 \%$ of couples invest everything. Higher rates of investment are found in some treatments, but in no case does the mean rate of investment exceed $80 \%$.

2. With few exceptions, the investment figures for Tamil Nadu are significantly below those for the northern sites. This applies to both men and women and across treatments. Men and women rarely invest all their endowment in the south and are more likely to keep the majority of their endowment themselves. For example, from these 5 treatments 116 women invest everything: 82 in urban Uttar Pradesh, 26 in rural Uttar Pradesh and only 3 in Tamil Nadu. For men the corresponding figures are 87, 55 and 2. The south also differs in the responses to treatments as we discuss further in points 5 and 6 .

3. In the rural areas, women generally invest less than men. Although the overall gap is highly significant, differences within treatments are not always significant. In urban Uttar Pradesh, there are no significant differences between male and female investment rates, which are similar across treatments. In addition as we discuss below the response to treatment varies between rural sites.

4. The two northern sites are clearly distinct from the south and there are many similarities between them. However, in general investment rates are higher in the urban location, particularly for women. For instance, the average investment rate for women across the 5 comparable treatments in Table 8 is significantly higher at the $1 \%$ level (Mann-Whitney test) in the urban area, compared to the rural Uttar Pradesh sites.

5. Comparing behaviour across treatments, the effects of control (perhaps better labelled responsibility), are ambiguous. Generally assigning control to one person (i.e. comparing the baseline investment treatment to either of the control treatments), lowers investment rates for both sexes. The effect is particularly stark in urban Uttar Pradesh. Compared to female control, male control produces higher investment rates for men and women in the same site, but elsewhere, there are marginal, but not significant falls in female investment and rises in male investment as control is moved from wife to husband. .iii $^{\text {in }}$

6. We hypothesised above that making endowments transparent may raise investment rates. Theory suggests this and there is some, conflicting evidence from other experiments. Here, for men there is a significant difference between the baseline and public treatments, but it is in the unanticipated direction: men invest less when all decisions are revealed to spouses. For women the treatment effect differs sharply between regions. In the north, investment appears to be higher in the public treatment, although this difference is not significant even if we pool the two northern sites. In the south, investment by women falls in the public treatment to under $40 \%$ of endowments. The difference between baseline and public treatments is significant at the $1 \%$ level (Mann-Whitney test, two-tailed). So 
we can conclude that in the south both men and women invest less in the public treatment.

7. Except amongst women in rural Uttar Pradesh there is no significant effect on investment from asking subjects to earn their endowments. Investment amongst women in rural Uttar Pradesh rises significantly when endowments are produced, but elsewhere and for men we find no statistically significant pattern.

Next we report regression results for the investment decision to see if our conclusions are robust to the introduction of controls. Given that the fraction of endowment invested data is censored at 1 and 0 and since we have a reasonable number of subjects who invest all their endowments, we use a Tobit model. In Table 11, for the first regression without controls we see the same basic features of the data that are already reported: investment by women is highest in the Northern urban setting. In the next two columns we consider interaction effects. In the same setting investment is lower when females control the allocation. In the rural Uttar Pradesh location, treatments have no significant impact on investment, except earning the endowment, which has a positive impact. In the south there are no significant treatment effects save for the public endowment treatment at the $5 \%$ level (two sided t-test).

In the final two columns of Table 11, we see results when controls are included. The equation shown reflects a number of features in which the controls are grouped into three broad groups (which potentially overlap). First we have the standard demographic characteristics. Then we have some potential measures of bargaining power, such as distance to parent's house and number of relatives living nearby. Finally we have the questionnaire responses about the state and organisation of the marriage. In interpreting the results, it is worth first noting that a large variety of controls were tried. Though they are largely significant we have left in standard demographic characteristics, in part because we anticipate that readers will be curious about their correlation with game play. With the other groups of variables we have been selective, dropping variables with low p-values and selecting one from a group of variables when there were high levels of collinearity. ${ }^{\text {xiv }}$ We also include the fraction believed to be invested by the spouses' partner, omission of which might cause bias in the estimated coefficients. Inclusion though is problematic since the partner's contribution and therefore beliefs about it are potentially endogenous. In theory instruments can be used for the belief variable. In practice though, it is almost impossible to find variables that influence one partner's decisions but not beliefs about those made by the other partner. In the case of female investment, we use distance to mother's house and number of relatives living with 15 minutes as instruments. A Wald test does not reject the null of non-endogeneity $(p=0.95)$ and so we present results in which belief about partner's investment is not instrumented.

When we look at the results for women, we see that first the conclusions of the previous section largely stand: women invest less in the south and most in the urban north. The apparent source of this effect though is intriguing since the simple regional dummies are 
positive for the south and insignificant for the rural north. However, while the coefficient on beliefs about partner's investment is 0.810 for the urban north and highly significant, it is only $0.087(=0.810-0.723)$ and insignificant for the south. The rural north is somewhere in between these two values, but also significantly different from zero. So, if we treat beliefs as exogenous, then it is as if women reciprocate male investment in the north, but choose their investments independently of men in the south. Moreover, compared to women in the south, wives in the urban north also believe their husbands will invest more ( 0.67 on average versus 0.46 in the south and 0.57 in the rural north) and this coupled with the higher beliefs coefficient drives the regional differences in investment levels.

When we consider the controls, standard demographic variables are largely insignificant. The exception is years of marriage and the dummy for non-membership of scheduled caste or scheduled tribe. For women there is evidence about whether proximity to family raises investment levels. Living closer to mother is associated with higher investment. Meanwhile living with a mother-in-law (which is common in all three regions) is linked to higher investment in the northern urban sites, but has no significant effect elsewhere, even in the rural north. There is some evidence that other measures of decision-making power are associated with investment levels: working on her own (non-farm) business is associated with higher investment for women. There is also some evidence that women invest less when they feel that they have less leisure than their husbands. Quantitatively the largest effects for women are her beliefs about her partner's investment, region, non-membership of a scheduled caste, tribe or other backward group, having her own business and living within half a day of travel to her mother.

Below the table for women we have the corresponding table for men. As with the table for women, we considered a number of other potential explanatory variables to the ones shown, none of which were stable or robust to changes in the specification. We also examined the endogeneity of male beliefs and accepted the null of exogeneity in a Wald test. As for women, however, we do not have good instruments for beliefs. In the investment behaviour, we see the lack of difference between the urban and rural sites in the north. When we add further controls a common feature is their lack of significance. There is a positive association between a husband's investment and his belief about what his wife has invested. Unlike women this correlation is not regionally sensitive, so that although men are not reciprocating as much as women in the north, they reciprocate more than women in the south. ${ }^{\mathrm{xv}}$ As with women there is some evidence of a quantitatively significant association between investment behaviour and not being a member of a scheduled tribe, or caste or other backward caste. 
Table 11a. Women's investment.

\begin{tabular}{|c|c|c|c|c|c|c|}
\hline \multirow{2}{*}{$\begin{array}{l}\text { Dependent variable: Fraction of } \\
\text { endowment invested by women }\end{array}$} & \multicolumn{2}{|l|}{ Basic } & \multicolumn{2}{|c|}{ Site interactions } & \multicolumn{2}{|c|}{ With controls } \\
\hline & Coeff. & t-stat & Coeff. & t-stat & Coeff. & t-stat \\
\hline Constant & $0.759^{\star \star \star}$ & 21.7 & $0.790^{\star \star \star}$ & 15.6 & 0.145 & 1.31 \\
\hline North, Rural & $-0.182^{\star \star *}$ & -5.60 & $-0.299^{\star * *}$ & -4.26 & 0.0547 & 0.59 \\
\hline South, Rural & $-0.314^{* * *}$ & -9.71 & $-0.290^{* * *}$ & -4.14 & $0.304^{\star \star *}$ & 3.26 \\
\hline Female control & $-0.0769^{*}$ & -1.88 & $-0.241^{* * *}$ & -3.43 & $-0.207^{* * *}$ & -3.15 \\
\hline Male control & -0.0311 & -0.76 & -0.0745 & -1.05 & -0.0464 & -0.71 \\
\hline Public endowment & 0.0205 & 0.50 & 0.0966 & 1.32 & 0.0560 & 0.83 \\
\hline Earned endowments & $0.130 * * *$ & 3.12 & 0.113 & 1.53 & 0.0696 & 1.01 \\
\hline North, Rural x Female control & & & $0.292^{\star \star \star}$ & 2.97 & $0.285^{\star * *}$ & 3.15 \\
\hline North, Rural x Male control & & & 0.116 & 1.17 & 0.0969 & 1.08 \\
\hline North, Rural x Public endowment & & & -0.00061 & -0.006 & -0.0148 & -0.16 \\
\hline North, Rural x Earned endowments & & & $0.176^{*}$ & 1.73 & $0.167^{*}$ & 1.80 \\
\hline South, Rural x Female control & & & $0.198^{* *}$ & 2.02 & $0.153^{*}$ & 1.74 \\
\hline South, Rural x Male control & & & 0.0114 & 0.12 & -0.0264 & -0.30 \\
\hline South, Rural x Public endowment & & & $-0.215^{\star \star}$ & -2.15 & $-0.168^{*}$ & -1.86 \\
\hline South, Rural x Earned endowments & & & -0.122 & -1.22 & -0.0928 & -1.01 \\
\hline Belief about spouse's investment & & & & & $0.818^{* * *}$ & 9.99 \\
\hline North, Rural x Belief & & & & & $-0.359^{* * *}$ & -3.13 \\
\hline South, Rural x Belief & & & & & $-0.725^{\star * *}$ & -6.43 \\
\hline Household size & & & & & 0.00418 & 0.67 \\
\hline Number of children & & & & & 0.00538 & 0.50 \\
\hline Husband's income & & & & & $-3.32 e-07$ & -0.94 \\
\hline Wife's income & & & & & $-1.52 \mathrm{e}-06$ & -1.38 \\
\hline Husband's age & & & & & -0.000337 & -1.24 \\
\hline Wife's age & & & & & -0.000503 & -0.14 \\
\hline Years married & & & & & 0.000852 & 0.26 \\
\hline Has no education (dummy) & & & & & -0.0296 & -1.13 \\
\hline Scheduled tribe dummy & & & & & -0.107 & -1.40 \\
\hline Scheduled caste dummy & & & & & 0.0128 & 0.51 \\
\hline Other group dummy & & & & & $0.113^{* *}$ & 2.14 \\
\hline Living with mother-in-law (MIL) & & & & & $0.169^{* * *}$ & 3.59 \\
\hline North, Rural x MIL & & & & & $-0.178^{* * *}$ & -2.78 \\
\hline South, Rural x MIL & & & & & $-0.214^{* * *}$ & -3.58 \\
\hline Works on her own business & & & & & $0.0958^{* *}$ & 2.40 \\
\hline More than $1 / 2$ day to mother's house & & & & & $-0.102^{* *}$ & -2.01 \\
\hline Your marriage (omitted: other) & & & & & & \\
\hline Husband earns and gives most & & & & & 0.0424 & 1.02 \\
\hline Husband earns most and gives some & & & & & 0.0320 & 0.79 \\
\hline Both spouses earn money and keep it & & & & & 0.0362 & 0.72 \\
\hline Wife must consult before buying sari & & & & & -0.0216 & -0.90 \\
\hline $\begin{array}{l}\text { Best to hand money to wife }(1= \\
\text { strongly agree) }\end{array}$ & & & & & $-9.70 e-05$ & -0.49 \\
\hline She has more leisure time dummy & & & & & 0.0424 & 1.02 \\
\hline $\mathrm{N}$ & 600 & & 600 & & 568 & \\
\hline Invested nothing & 12 & & 12 & & 12 & \\
\hline Invested all & 111 & & 111 & & 100 & \\
\hline Log likelihood & -250.5 & & -236.2 & & -132.7 & \\
\hline
\end{tabular}




\section{Table 11b. Men's investment.}

\begin{tabular}{|c|c|c|c|c|c|c|}
\hline \multirow{3}{*}{ Variable: Men's investment } & \multicolumn{6}{|c|}{ Site } \\
\hline & \multicolumn{2}{|c|}{ Basic } & \multicolumn{2}{|c|}{ interactions } & \multicolumn{2}{|c|}{ With controls } \\
\hline & Coeff. & t-stat & Coeff. & t-stat & Coeff. & t-stat \\
\hline Constant & $0.763^{* * *}$ & 21.71 & $0.792^{* * *}$ & 15.34 & $0.672^{* * *}$ & 4.79 \\
\hline North India, Rural & -0.0291 & -0.90 & -0.0673 & -0.92 & -0.00616 & -0.06 \\
\hline South India, Rural & $-0.164^{* * *}$ & -5.09 & $-0.211^{* * *}$ & -2.95 & $-0.326^{* * *}$ & -3.08 \\
\hline Female control & $-0.135^{\star \star *}$ & -3.26 & $-0.227^{\star \star *}$ & -3.16 & $-0.193^{\star * *}$ & -2.65 \\
\hline Male control & $-0.0834^{\star *}$ & -2.01 & $-0.138^{*}$ & -1.92 & -0.0830 & -1.19 \\
\hline Public endowment & $-0.0801^{*}$ & -1.93 & -0.0320 & -0.44 & -0.0421 & -0.60 \\
\hline Earned endowments & 0.0286 & 0.68 & -0.0154 & -0.21 & -0.000241 & -0.00 \\
\hline North, Rural x Female control & & & 0.122 & 1.20 & 0.146 & 1.45 \\
\hline North, Rural x Male control & & & 0.0488 & 0.48 & 0.0420 & 0.42 \\
\hline North, Rural x Public endowment & & & -0.0701 & -0.69 & -0.00915 & -0.09 \\
\hline North, Rural x Earned endowments & & & 0.0899 & 0.87 & 0.0766 & 0.78 \\
\hline South, Rural $x$ Female control & & & 0.152 & 1.51 & 0.108 & 1.12 \\
\hline South, Rural x Male control & & & 0.113 & 1.13 & 0.0743 & 0.79 \\
\hline South, Rural x Public endowment & & & -0.0720 & -0.71 & -0.0424 & -0.45 \\
\hline South, Rural x Earned endowments & & & 0.0428 & 0.42 & -0.0192 & -0.20 \\
\hline Belief about spouse's investment & & & & & $0.460^{* * *}$ & 5.53 \\
\hline North, Rural x Belief & & & & & -0.124 & -1.04 \\
\hline South, Rural x Belief & & & & & 0.201 & 1.53 \\
\hline Household size & & & & & -0.00219 & -0.32 \\
\hline Number of children & & & & & -0.0114 & -0.98 \\
\hline Husband's income & & & & & $2.49 e-07$ & 0.60 \\
\hline Wife's income & & & & & $-8.31 e-08$ & -0.07 \\
\hline Husband's age & & & & & -0.00337 & -1.10 \\
\hline Wife's age & & & & & -0.000997 & -0.89 \\
\hline Years married & & & & & 0.00333 & 1.09 \\
\hline Has no education (dummy) & & & & & -0.0110 & -0.37 \\
\hline Scheduled tribe dummy & & & & & 0.0695 & 0.84 \\
\hline Scheduled caste dummy & & & & & -0.0335 & -1.21 \\
\hline Other group dummy & & & & & $0.0981^{*}$ & 1.71 \\
\hline \multicolumn{7}{|l|}{ Living within 15 mins: } \\
\hline Number of husband's relatives & & & & & 0.000159 & 0.84 \\
\hline Number of wife's relatives & & & & & 0.000468 & 1.36 \\
\hline Wife's time to travel to mother's house & & & & & -0.00642 & -0.12 \\
\hline \multicolumn{7}{|l|}{ Your marriage (omitted: other) } \\
\hline Husband earns and gives most & & & & & -0.0129 & -0.22 \\
\hline Husband earns most and gives some & & & & & -0.0297 & -0.49 \\
\hline Both spouses earn money and keep it & & & & & -0.0272 & -0.41 \\
\hline Wife must consult before buying sari & & & & & 0.0271 & 0.98 \\
\hline $\begin{array}{r}\text { Best to hand money to wife }\left(\begin{array}{r}\text { = strongly } \\
\text { agree })\end{array}\right.\end{array}$ & & & & & 0.0123 & 0.67 \\
\hline \multicolumn{7}{|l|}{ Leisure (omitted: she has more) } \\
\hline Equal leisure time & & & & & -0.0419 & -0.92 \\
\hline He has more leisure & & & & & -0.0211 & -0.45 \\
\hline $\mathrm{N}$ & 600 & & 600 & & 551 & \\
\hline Invested nothing & 19 & & 19 & & 18 & \\
\hline Invested all & 108 & & 108 & & 92 & \\
\hline Log likelihood & -264 & & -260.2 & & -176.7 & \\
\hline
\end{tabular}




\section{Allocation behaviour: during and after the experiment.}

The main focus of the paper is on the investment decision, but we now briefly analyse the allocation to wives in the female and male control treatments. As Iversen et al, 2006, note allocation involves intrahousehold transfers which are potentially reversible after the experiment. In that sense such decisions are different to investment choices, which affect the total returns to the household. Nevertheless, allocation decisions can be informative about patterns of money-sharing within the household whenever there some deviation from incomepooling. For both male and female control treatments we used a strategy method to elicit allocations conditional on the partner's investment. This provides 5 data points per household (i.e. allocations based on 0, 40, 80, 120 and 160 Rupees by the partner). Table 12 summarises the results. Note that a coefficient of 1.5 on the decision-maker's investment means that at the margin all of the returns from this investment are returned to the investor. For each spouse we show three specifications: one without controls (random effects) and a fixed and random-effects specification using the same control variables. For both sexes a Hausman tests accepts the null of no difference in the comparable coefficients at high probabilities ( $p=0.998, p=0.885$ for women and men respectively), suggesting that the random effects estimator is preferable.

There are some stark differences between male and female allocation behaviour. Female allocation to herself is highly correlated with her own investment and with that of her partner's. She gives her spouse half of the marginal returns from her own investment, but slightly less from his investment. There are no significant site effects on the treatment of own investment, but there are for her husband's investment. Notably, women in the two rural areas take significantly more of their husband's investment. Women also take more from their spouses' investment when more of their husband's relatives live close by, when the wife has relatively more leisure (as she sees it) and when she has her own business. These effects are large, in the sense that for a woman with none of her husband's relatives close by, where husband has more leisure and where she works on her own business, her marginal take from her husband's investment is close to 0.15 for an urban, Northern woman. Conversely, if she lives in the south, has more leisure, an average number of husband's relatives living close by and she does not have her own business, the take from her spouse's investment is close to 1.35. For women, the other, demographic variables have little explanatory power, whether they are entered (as in the specification shown) on their own or via interaction terms with spousal investment.

If we consider Table 12b, the male intercept is positive, but not significant. The marginal return to the wife from the husband's investment is not significantly different from 1.5. In other words the typical husband gives his wife all the marginal returns from his own investment. He also claims only a fraction 0.211 of her investment, meaning that she gets 1.279 from each 1 rupee invested. There are no significant site effects for the coefficient on his investment, but 
men in the rural north give less back to their wives compared to urban men and men in the south.

Table 12a Female Allocation in the Experiment.

\begin{tabular}{|c|c|c|c|c|c|c|}
\hline \multirow[t]{2}{*}{ Dependent variable: allocation to self (Rupees) } & \multicolumn{2}{|c|}{$\begin{array}{c}\text { Basic, } \\
\text { Random } \\
\text { effects }\end{array}$} & \multicolumn{2}{|c|}{$\begin{array}{l}\text { With controls, } \\
\text { Fixed effects }\end{array}$} & \multicolumn{2}{|c|}{$\begin{array}{l}\text { With controls, } \\
\text { Random effects }\end{array}$} \\
\hline & Coeff. & t-stat & Coeff. & t-stat & Coeff. & $\overline{\text { t-stat }}$ \\
\hline Constant & -11.74 & -0.70 & $64.75^{\star \star \star}$ & 24.78 & 5.076 & 0.20 \\
\hline Own investment & $0.927^{* * *}$ & 5.52 & & & $0.723^{\star * *}$ & 5.73 \\
\hline \multicolumn{7}{|l|}{ Site (omitted: Urban north) } \\
\hline Rural North & 18.71 & 0.67 & & & -7.199 & -0.53 \\
\hline Rural South & 32.12 & 1.28 & & & -1.374 & -0.10 \\
\hline Spouse's investment & $0.824^{\star \star *}$ & 17.94 & $0.921^{* * *}$ & 9.79 & $0.918^{* * *}$ & 10.43 \\
\hline \multicolumn{6}{|l|}{ Own investment $x$} & \\
\hline Rural South & -0.360 & -1.28 & & & & \\
\hline \multicolumn{7}{|l|}{ Spouse investment $\mathrm{x}$} \\
\hline Rural North & $0.190^{* * *}$ & 2.92 & $0.189^{* * *}$ & 2.68 & $0.193^{* * *}$ & 2.78 \\
\hline Rural South & 0.0825 & 1.27 & $0.233^{* * *}$ & 3.17 & $0.243^{* * *}$ & 3.38 \\
\hline $\begin{array}{r}\text { Number of husband's relatives living within } 15 \\
\text { mins }\end{array}$ & & & $0.0068^{* * *}$ & 4.11 & $0.0073^{* * *}$ & 4.91 \\
\hline Number of wife's relatives living within 15 mins & & & -0.00059 & -0.31 & -0.00049 & -0.28 \\
\hline More than $1 / 2$ day to mother's house & & & -0.122 & -1.35 & -0.104 & -1.27 \\
\hline \multicolumn{7}{|l|}{ Leisure dummy (omitted: she has more leisure) } \\
\hline Equal leisure time & & & $-0.137^{\star}$ & -1.69 & $-0.146^{\star *}$ & -1.97 \\
\hline He has more leisure & & & $-0.416^{\star * *}$ & -4.58 & $-0.440^{* \star *}$ & -5.34 \\
\hline Works on her own business & & & $-0.275^{\star \star}$ & -2.57 & $-0.302^{* * *}$ & -3.11 \\
\hline Household size & & & & & 0.638 & 0.22 \\
\hline Numbe & & & & & -0.547 & -0.12 \\
\hline Husband's income & & & & & $4.71 e-05$ & 0.18 \\
\hline Wife's income & & & & & -0.000183 & -0.52 \\
\hline Husband's age & & & & & -0.563 & -0.42 \\
\hline Wife's age & & & & & 0.556 & 0.40 \\
\hline Years married & & & & & 0.0011 & 0.04 \\
\hline Wife has no education (dummy) & & & & & 14.19 & 1.26 \\
\hline \multicolumn{7}{|l|}{ Caste (omitted: OBC) } \\
\hline Scheduled caste & & & & & 30.83 & 1.00 \\
\hline Other backward caste & & & & & -9.322 & -0.93 \\
\hline Other & & & & & -5.325 & -0.25 \\
\hline of groups & 120 & & 112 & & 112 & \\
\hline Number of observations & 600 & & 560 & & 560 & \\
\hline $\mathrm{R}^{2}$ within & 0715 & & - & & 0.738 & \\
\hline$R^{2}$ between & 0.291 & & - & & 0.398 & \\
\hline
\end{tabular}

Notes: ${ }^{* * *} p<0.01,{ }^{* *} p<0.05,{ }^{*} p<0.1 ;$ OBC $=$ Other backward caste. Based on answers from the 'female control' treatment. Variables below 'spouse investment $x$ ' to 'household size' are interacted with spouse investment.

For men, there is very little correlation between other variables and allocation to the wife. An exception is the 'best description of the household' variable, where we see that husbands tend to allocate more to themselves when they perceive that both spouses earn money and keep it. Against this, men give a higher return to wives when the women live further from their 
mother's home. Men also give more to wives with low or no education, at the margin and in lump-sum form. Other standard demographic variables explain very little of the variation. Age, household size, income and number of children have no significant effect. We also tried specifications that included occupation for instance, but again there was no evidence of correlation.

Table 12b Male Allocation to Wife in the Experiment.

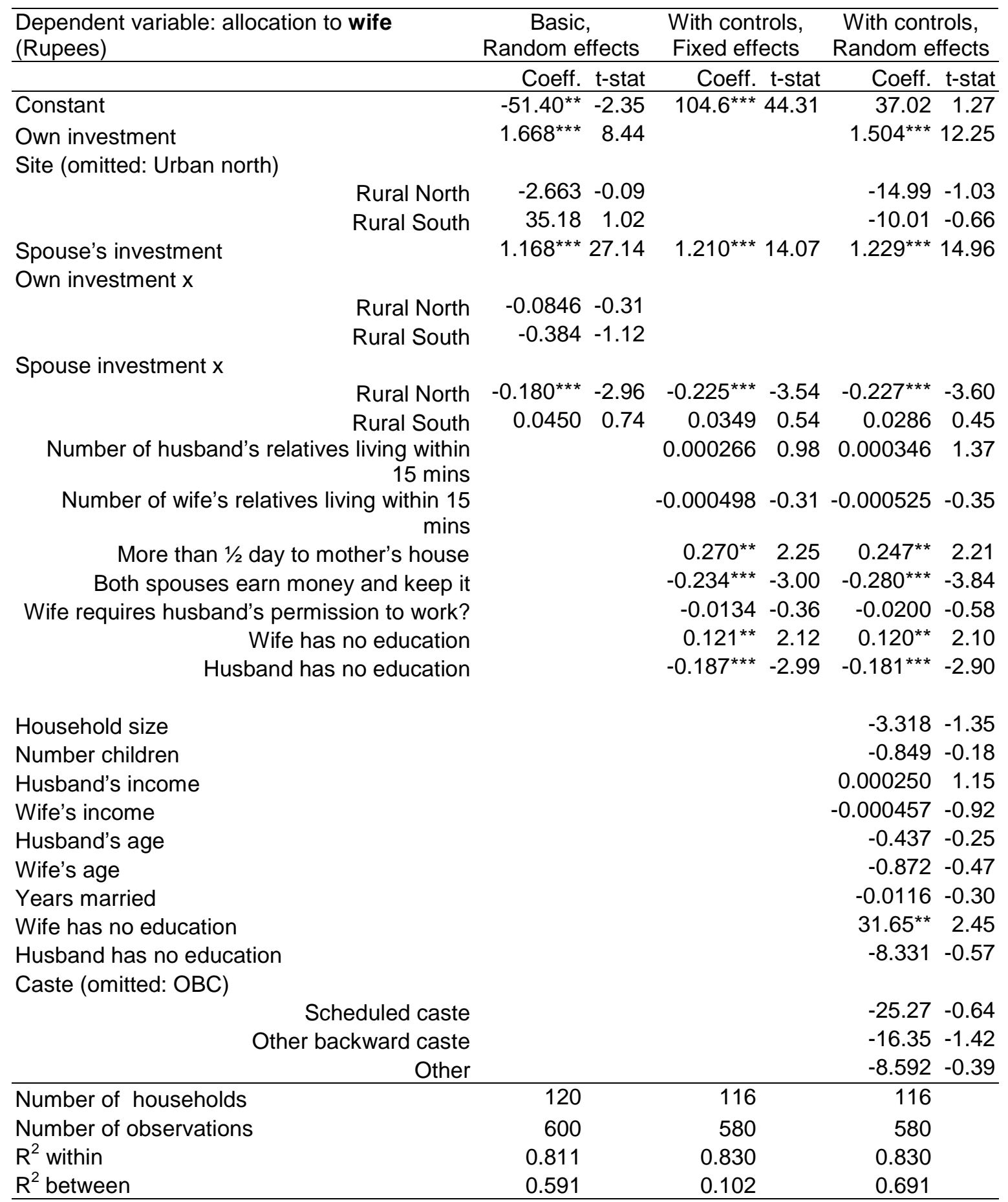

Notes: ${ }^{* * *} p<0.01,{ }^{* *} p<0.05,{ }^{*} p<0.1 ;$ OBC $=$ Other backward caste. Based on answers from the 'male control' treatment. Variables below 'spouse investment $x$ ' to 'household size' are interacted with spouse investment. 
It is interesting to consider briefly the implications of taking the allocation data at face value and comparing it to the baseline treatment in which each partner faced a marginal return of 0.75 from investing in the pool. With male control the female return to her investment exceeds 1.2 and is significantly higher than 0.75 at the $1 \%$ significance level. This would suggest a greater incentive for women to invest. Nevertheless female investment is generally lower than in the baseline. This is a puzzle; it may be the result of a biased prediction of the husband's behaviour but it is also consistent with female risk aversion in the face of uncertainty over the rule the husband would follow.

After the experiment, as part of the household survey, we asked questions about subject's perceptions of their partner's behaviour and also about what they did with the winnings after the experiment. Some results are summarised in Table 13, where we use the whole sample. As with the other data, we have stark differences between north and south. In line with the regional differences in autonomy, both men and women in the south were more likely to keep all their winnings compared to the northern subjects. Female subjects in the north favoured their children as recipients, whereas in the south the gap between spouse and kids as targets was smaller. Conversely, in the north, men were more likely to favour spouses than their children, a gap that was all but closed in the south. Wives in the south believed that men gave money away about half as frequently as men said that they passed on winnings. Meanwhile, men underestimated their wives' propensity to hang on to winnings in the south.

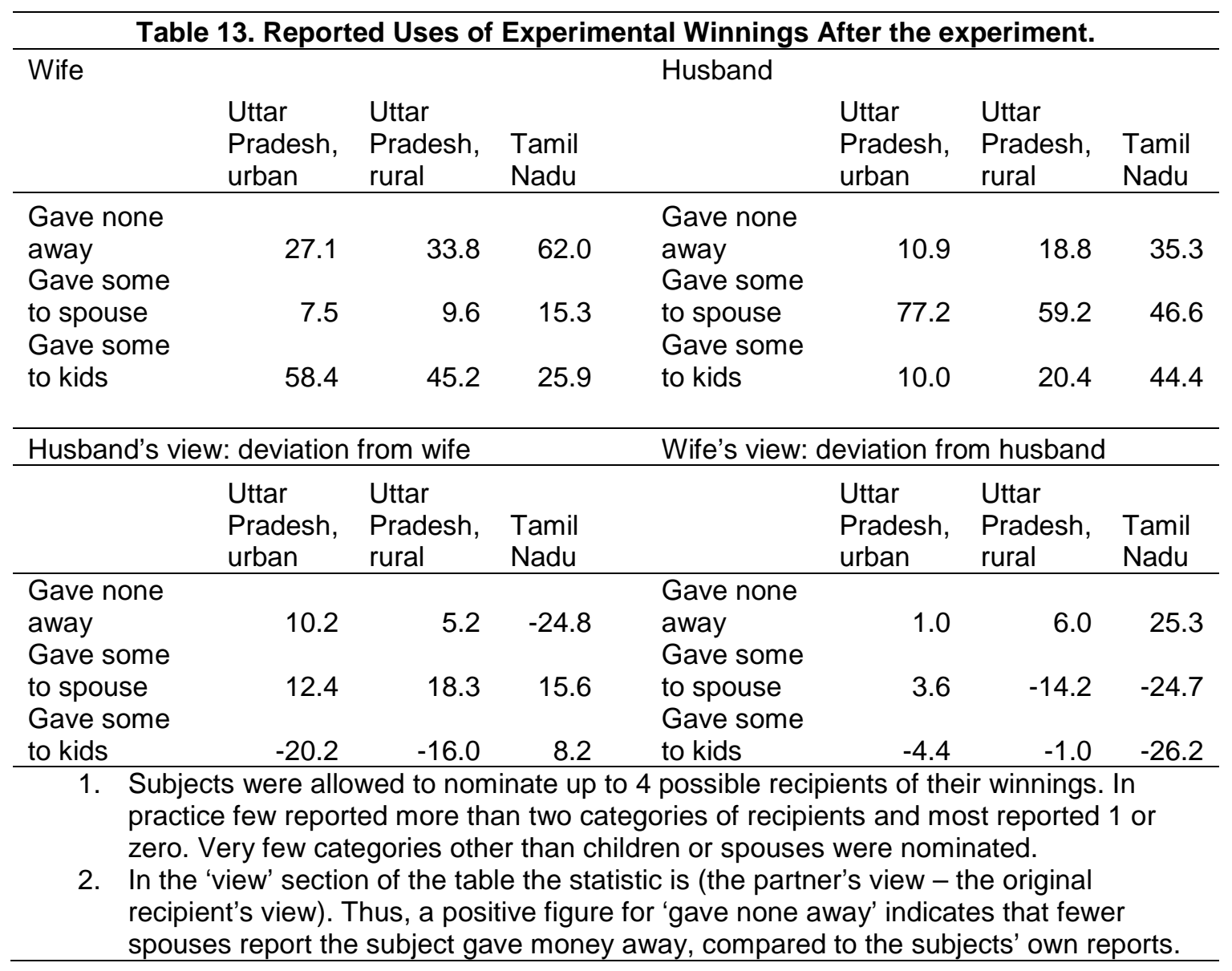


About $25 \%$ of men in urban Uttar Pradesh report that they gave all their money away. Other groups report much lower figures. It is notable that $75 \%$ of men but only $30 \%$ of women in the south refused to say what they did with money they kept. In the north the relevant percentages were around $40 \%$ with no significant gap between the sexes. Out of those willing to reveal their expenditure plans, saving for the future was the most popular category amongst southern women (115 out of 400 nominated it first), whereas spending on the household as a whole topped the list in the north for women (117 out of 400). Spending on children ranked second in the north and third in the south, behind spending on the household. Saving for the future was nominated by only a handful of women in the north. Recall that very few southern men would reveal what they did with their winnings, but amongst northern men, spending on themselves and spending on the household were the equally likely categories, with children someway behind. As with the wives, savings were nominated by less than $5 \%$ of the participants who retained some money.

\section{Discussion.}

We have conducted a large scale experiment with 2400 people and an accompanying survey in three distinct locations in India. The survey data confirms the continuing existence of prominent differences in the conjugal circumstances of households between north and south. Differences between urban and neighbouring rural communities in the north are less sharp. The social distinctions between north and south are mirrored in the way participants played the games: investment was generally closer to its maximum possible limit in the north for both men and women. Nevertheless in all our locations putting all into the common pool by both spouses was an uncommon strategy, in contrast to the results obtained by Iversen et al, 2010 where, for similar games played amongst couples in Uganda, the modal choice was full investment. For our games the modal investment was $75 \%$ of endowment for men and just $25 \%$ for women. As such our results have more in common with those of Mani's (2008) experiment in Andhra Pradesh where couples typically passed on the opportunity to maximize the household's total payoff from the game.

The intriguing results of the full information treatment suggest that an unwillingness to invest all the endowment is not driven by the opportunity to hide money from spouses. In fact men invested less in the full information treatment in all our sites, while investment rose for women in the north, but fell in the south. Such results are in keeping with those found in our nonIndian sites, and also with the results of Munro et al, 2007. There is no evidence in our postexperiment surveys and interviews that individual spouses doubted their ability to hide payoffs from their partners. 
Comparing regions, the broad outlines of our results are compatible with a theory where there is a trade-off between autonomy and efficiency, such as Lundberg and Pollak's separate sphere's model. In Tamil Nadu, where women have more autonomy their investment in the common pool is lower. This suggests that more opportunities for spouses' mutual gains are left unrealised in the region with greater female autonomy. It is not of course to suggest that this female autonomy is not worth having, nor to close our eyes to the numerous benefits we know it brings: lower fertility, better child health and education, as well as a lower gender disparity in them, and so forth. It is simply to point out that there may be a price to pay for these good things in that household decision-making is less efficient.

Meanwhile, the regression yields evidence of almost no reciprocity amongst women in the south. Within regions the results are suggestive of a link between autonomy and efficiency but not definitively so: variables such as having her own business play a part in explaining variation in investment rates in the regression analysis, but measures of household say are largely insignificant and there remain some quantitatively significant north south differences in the way the games are played that are not captured by differences in answers to standard questionnaires about conjugality. Of notable interest is the fact that women invest less if their mothers live further away. Living with a mother-in-law is associated with a significant positive effect on investment in the urban north, but not elsewhere.

Sen (1990) conjectured that women identify more closely than men with the household as a whole, which would lead them to contribute more to the common pool than men. Yet, even in the treatments where females are in control of allocation wives typically contribute less than their husbands. ${ }^{\text {xvi }}$ The larger investments by husbands are consistent with a conjugal world in which husbands are expected to provision the household and wives' contribution is discretionary. In fact, control may be a misnomer here; rather it is responsibility that may be assigned by the treatment and it seems that men and women respond in different ways to the burden. In every location, men invest less than in the baseline when one or other partner is assigned responsibility for dividing the common pool. Meanwhile, when allocating the payoffs our regression results indicate that men favour spouses over themselves while women favour themselves. If men take the allocation rules embodied in these regressions as a given, their treatment response to changes in control is consistent with a degree of self-interest on men's part - i.e. they invest less because they know they will receive less back. Women's response to changes in responsibility varies across regions: investment falls compared to the baseline in the south and the urban north, but it rises in the rural north, albeit only slightly. What men do and women do in rural Uttar Pradesh is mutually consistent ${ }^{\text {xvii }}$, but in the other two locations, the responses of men and women are mutually inconsistent, unless we allow for some other intervening factor such as errors in expectations about the behaviour of their partners. In fact Table 13 gives support for such an explanation in Tamil Nadu: there we saw a significant mismatch between the reports of wives and husbands in the south. That still 
leaves unresolved the results in urban Uttar Pradesh and here we can only speculate. We noted earlier that risk aversion may play a role in investment decisions when individuals do not know how the proceeds will be finally allocated. In such a situation a move from a fixed allocation rule to one where an individual partner divides the pool can lead to an outcome in which both partners lower investment. Further research will be needed. 


\section{Endnotes.}

'The review of ethnographies they rely on is Karve's (1965) Kinship Organization in India,
while adopting Sopher's (1980) and Miller's (1981) understanding of how northern and
southern kinship structures respectively translate into gender relations and discrimination.

ii "[Whereas] the ultimate historical "cause" of differences between north and south may lie in agrarian ecology [...] [c]ontemporarily [...] there simply is no clear spatial correspondence between cultural variation [...] and differences in agrarian ecology' (Dyson and Moore 1983: 47).

iii This study, reported on in Jejeebhoy (2001) and in Jejeebhoy and Sathar (2001), uses for its India component a sample of 1,842 women; the fieldwork took place in 1993/94.

${ }^{\text {iv }}$ As an aside, we note that questions about female autonomy are often asked only to female respondents. In our case we ask both male and female spouses questions about female autonomy, which in some cases provides interesting contrasts in responses.

${ }^{v}$ It is known (reference) that generally in such models each spouse contributes to a distinct set of household public goods. Thus Lundberg and Pollak's assumption that the spouses control separate spheres can be relaxed without materially changing the outcome of their model.

${ }^{v i}$ Generically, in the sense that if for instance there are no household public goods then $y^{\text {h }}=0$ can yield efficiency.

vii The factors which raise autonomy may also influence the weight, $\lambda$ in the second stage of the model. Such changes can alter the observed relationship between autonomy and efficiency. For instance, consider a rise in female power that increases $\lambda$ and $y^{f}$ simultaneously. If the change in $\lambda$ is sufficiently large, then the outcome of the first stage of the game may no longer constrain the solution to the second stage. In other words, the rise in female power increases efficiency. However, as long as consider changes in autonomy keeping $\lambda$ constant the inverse relationship between autonomy and efficiency holds.

viii We also had 2-3 days of training for the survey enumerators.

${ }^{\text {ix }}$ Major differences between samples: we include a sample of nearly 400 from urban Uttar Pradesh; we interview both men and women. Our sites are geographically more clustered and are subjects are overwhelmingly Hindu (by design). Rahman and Rao also by design include a variety of different levels of prosperity in their sample.

${ }^{x}$ Our figures for dowries are substantially lower than those given in Rahman and Rao. We selected low income villages and urban districts, whereas in each region they chose 2 prosperous districts out of 5 in total. They also report a very high variance, which suggests that a relatively small number of large dowries may drive their figures.

${ }^{\mathrm{xi}}$ For instance, what food to prepare for family meals, whether to purchase major goods for the household such as a (TV)? whether or not you should work outside the home? How many children to have? Whether to purchase or sell gold/silver jewellery? Inviting guests to your home? What to do if a child falls sick? How much schooling to give your children? To whom to marry your children? How overall household income is spent? These questions are very similar to those asked in Rahman and Rao, but we simplify the answering format, with subjects asked to nominate the primary decision-maker and then a secondary decision-maker if appropriate.

${ }^{x i i}$ In the underlying questions responses were typically - though not exclusively - more extreme in Uttar Pradesh. This raises the probability that a partner picked randomly from the 
sample would give a similar answer. In other words, the picture of marital congruence in the north might be overstated from these figures.

xiii Iversen et al, 2006 report that assigning responsibility to women raises investment by both men and women. The different results here underline the 'one size does not fill all' conclusion of the earlier paper.

${ }^{\text {xiv }}$ For such variables, such as the variables for control and say in marriage we have also tried factor analysis and indices. This did not produce results significantly different or superior to the ones shown.

${ }^{x v}$ In bivariate correlations, men's beliefs about women's investment are more accurate than women's beliefs about male investment.

xvi This is obviously an average. In fact, in about $40 \%$ cases men investment more than wives, in $32 \%$ cases men and women invest the same and in $28 \%$ of households it is women who invest the most. Even in Tamil Nadu, $21 \%$ of wives invest more than their husbands, a sharp reminder of the diversity of responses in our experiment.

xvii Rural Uttar Pradesh is also consistent with this interpretation for two other treatments that we ran there: one in which all the common pool goes to the wife and the trust game in which the wife invests and the husband allocates. In both cases wives invest significantly more than in the baseline. Meanwhile men's investment is lower in the trust treatment where men invest and the wife allocates. 


\section{References}

1. Agnihotri, Satish, Richard Palmer-Jones and Ashok Parikh 2002, 'Missing Women in Indian Districts: A Quantitative Analysis,' Structural Change and Economic Dynamics, Vol. 13, pp. $285-314$.

2. Anderson Siwan and Mukesh Eswaran, 2009, What determines female autonomy? Evidence from Bangladesh, Journal of Development Economics, 90(2), 179-191.

3. Ashraf, N. 2009, Spousal Control and Intra-Household Decision Making: An Experimental Study in the Philippines, American Economic Review.

4. Bardhan, P. 1974, 'Size, Productivity and Returns to Scale: An Analysis of Farm Level Data in Indian Agriculture,' Economic and Political Weekly 9, 6-8.

5. Bateman, I. and A. Munro, 2005, An experiment on risky choice amongst households, Economic Journal, 115, C176-C189.

6. Becker, G., 1981, A Treatise on the Family, Cambridge, Massachusetts and London, England: Harvard University Press.

7. Browning, M. and P-A Chiappori, 1998, "Efficient intra-household allocations: a general characterisation and empirical tests," Econometrica, 66 (6): 1241-1278.

8. Carlsson, Fredrik \& Martinsson, Peter \& Qin, Ping \& Sutter, Matthias, 2009. "Household Decision Making and the Influence of Spouses' Income, Education, and Communist Party Membership: A Field Experiment in Rural China," IZA Discussion Papers 4139, Institute for the Study of Labor (IZA).

9. Cherry, Todd L., Peter Frykblom, Jason F. Shogren, 2002, Hardnose the Dictator The American Economic Review 92, No. 4 (Sep), 1218-1221.

10. Cochard, François \& Couprie, Hélène \& Hopfensitz, Astrid, 2009. "Do Spouses Cooperate? And If Not: Why?," TSE Working Papers 09-134, Toulouse School of Economics (TSE).

11. Dubey Pradeep, 1986, Inefficiency of Nash Equilibria, Mathematics of Operations Research 11, No. 1, 1-8.

12. Dyson, Tim and Mick Moore, 1983, 'On Kinship Structure, Female Autonomy, and Demographic Behavior in India,' Population and Development Review, Vol. 9, No. 1 (March), pp. $35-60$.

13. Grossbard, A., 1978, Towards a Marriage Between Economics and Anthropology and a General Theory of Marriage," American Economic Review Papers and Proceedings, 68(2), 33-37.

14. Haddad, L., J. Hoddinott and H. Alderman, 1997, Intrahousehold resource allocation in developing countries: Methods, models and policy, John Hopkins University Press, Baltimore.

15. Iversen, V., C. Jackson, B. Kebede, A. Munro, and A. Verschoor, 2006, What's love got to do with it? An experimental test of household models in East Uganda, Discussion Papers in Economics 06/01, Department of Economics, Royal Holloway University of London 
16. Iversen, V., C. Jackson, B. Kebede, A. Munro, and A. Verschoor, 2010, Do Spouses Realise Cooperative Gains? Experimental Evidence from Rural Uganda, World Development, forthcoming.

17. Jejeebhoy, Shireen J. 2001, 'Women's Autonomy in Rural India: Its Dimensions, Determinants, and the Influence of Context,' in: Harriet B. Presser and Gita Sen (eds.), Women's Empowerment and Demographic Processes: Moving Beyond Cairo, New York: Oxford University Press.

18. Jejeebhoy, Shireen J. and Zeba A. Sathar 2001, 'Women's Autonomy in India and Pakistan: The Influence of Religion and Region,' Population and Development Review, Vol. 27, No. 4 (December), 687 - 712.

19. Karve, Irawati 1965, Kinship Organization in India, Bombay: Asia Publishing House.

20. Katz, E. 1992. Household Resource Allocation When Income Is Not Pooled: A Reciprocal Claims Model of the Household Economy. In Understanding How Resources Are Allocated Within Households. Policy Brief 8. Washington, D.C.: International Food Policy Research Institute.

21. Lundberg, S. and R. Pollak 1993: Separate spheres bargaining and the marriage market," Journal of Political Economy, 101 (6): 988-1010.

22. Mani, Anand, 2008, Mine, Yours or Ours: The Efficiency of Household Investment Decisions -- an Experimental Approach, Working Paper, Warwick University Economics Department

23. Manser, M and M. Brown 1980: Marriage and Household Decision-Making: A Bargaining Analysis," International Economic Review, 21 (1): 31-44.

24. Miller, B. 1984, 'Daughter Neglect, Women's Work and Marriage,' Medical Anthropology, Vol. 8, No. 2, pp. $109-125$.

25. Miller, Barbara D. 1981, The Endangered Sex, Ithaca, NY: Cornell University Press.

26. Munro, Alistair \& Bateman, lan J. and McNally, Tara, 2008. "The family under the microscope: an experiment testing economic models of household choice," MPRA Paper 8974, University Library of Munich, Germany.

27. Pahl, Jan, 1990: Household spending, personal spending and the control of money in marriage, Sociology, 24:1, 119-138.

28. Palma, Andre de, Nathalie Picard and Anthony Ziegelmeyer, 2007 Individual and Couple Decision Behavior under Risk:The Power of Ultimate Control Who controls the mouse controls the outcome of joint choice, forthcoming in Theory and Decision

29. Peters, E. H., A. N. Unur, J. Clark and W.D. Schulze, 2004: "Free-Riding and the Provision of Public Goods in the Family: A Laboratory Experiment," International Economic Review, 45 (1): 283-299.

30. Rahman, Lupin and Vijayendra Rao 2004, 'The Determinants of Gender Equity in India: Examining Dyson and Moore's Thesis with New Data,' Population and Development Review, Vol. 30, No. 2 (June), pp. $239-268$.

31. Robinson, Jonathan, 2008, Limited Insurance Within the Household: Evidence from a 
Field Experiment in Kenya

32. Sen, A. 1990, Gender and Cooperative Conflicts". In I. Tinker (ed.): Persistent Inequalities: Women and World Development, Oxford University Press, Oxford.

33. Sopher, David E. 1980, 'The Geographical Patterning of Culture in India,' pp. $289-326$ (chapter 10) in: David E. Sopher (ed.), An Exploration of India: Geographical Perspectives on Society and Culture, London: Longman.

34. Subramanian S. and D. Jayaraj, 2006 The Distribution of Household Wealth in India Research Paper No. 2006/116 WIDER.

35. Thomas, D. 1990, "Intrahousehold resource allocations - an inferential approach," Journal of Human Resources, 25 (4): 635-64.

36. Udry, C. 1996, "Gender, Agricultural Production and the Theory of the Household," Journal of Political Economy, 104 (5): 1010-1046. 
Appendix. An example of the Instructions: women in the Male control treatment.

\section{Instructions for Participants}

\section{[ both partners present]}

Welcome. Thank you for taking the time to come today. [Introduce EXPERIMENTERS and the assistants.] You can ask any of us questions during today's programme.

We have invited you here because we want to learn about how married couples in this area take decisions. We will ask you to make decisions about money. Whatever money you win today will be yours to keep.

You will be asked very simple questions. Questions that do not have a correct answer, they are just about the way you think. For example, what is your favourite colour [ask someone in the room]? We cannot say that this answer is right or wrong. It is just your opinion and it can be different from the opinion of others in this room. However it is important to think seriously about your answers because they will affect how much money you will take home.

What you need to do will be explained fully in a few minutes. But first we want to make a couple of things clear.

- First of all, this is not our money. We belong to a research organization, and this money has been given to us for research.

- Second, this is a study about how you make decisions. Therefore you should not talk with others. This is very important. Please be sure to obey this rule because it is possible for one person to spoil the activity for everyone. I'm afraid that if we find you talking with others, we will have to send you home, and you will not be able to earn any money here today. Of course, if you have questions, you can ask one of us.

- Third, the study has two parts: today's exercise is one, but we will also visit you in your homes in the coming weeks to ask both the husband and the wife a number of questions.

- Finally, make sure that you listen carefully to us. You will be able to make a good amount of money here today, and it is important that the instructions are clear for you so that you can follow them. 
Would wives now please go with [Thea] and husbands with [Theo]? The task will then be explained to you.

[Instructions for wife]

In a moment I will give you an envelope containing money. The exact amount will vary between people, but you will receive something between 0 and 160 rupees. [Show the envelope.] Your husband will receive a similar envelope and he will also receive an amount of money between 0 and 160 rupees. He doesn't know how much you have in your envelope and you won't be told how much he has in his envelope.

You have to decide how much money to take out of the envelope and how much to leave in. Any money you take out of the envelope is yours to keep. Your husband will be making the same decision with his envelope.

After you have made your decision and your husband has made his decision we will bring you together again. We will put all the money that you and your husband have left in your envelopes into one envelope. We call it, the common envelope. To whatever is in the common envelope we will add another half again. So, if there are 80 rupees in the common envelope we will add another 40 rupees to make the total 120 . If there are 320 rupees in the common envelope we will add another 160 rupees to make a total of 480 rupees and so on.

Both of you will know the total amount of money in the common envelope.

After that your husband will decide how to split the money in the common envelope. He has to decide how much to give to you and how much to keep for herself. In a moment we will give you some time to think about how much money you want to leave in your envelope.

Let me ask some questions to check whether you understood the instructions.

1. If you have 160 rupees in your envelope and you take out 80 rupees how much will be left in the envelope? [record the answer, correct participant if necessary]

2. If you put 80 rupees into the common envelope and your husband puts in 80 rupees how much will there be in total?

3. How much we will add if there is 160 rupees in the common envelope?

[Record each answer, correct participant if necessary] 
[Responses to common questions: to be used only when subjects ask]

1. If you are asked whether the husband and wife will have the same amounts in their envelopes, answer: possibly, possibly not.

2. If you are asked what 'what should I do', you should say that it is 'your decision and I am not allowed to offer advice'

3. If you are asked precise arithmetical questions then answer them precisely. E.g if I put in 160 rupees and my husband puts in nothing how much will you add to the total?' Answer: 80 rupees.

[Once the experimenter is sure that the participant has understood the activity, give him/her some time to make his/her decision in private. DON'T FORGET TO KEEP RECORD OF THIS DECISION.]

Thank you. We will now rejoin your husband and put the money from your two envelopes into the common envelope.

[Bring husband and wife together \& resolve the game.]

[Experimenter looks up the allocation decision and executes it. Subjects are given their money and thanked] 